\title{
Role of protein aggregation in heat-induced heat stability during milk powder manufacture
}

\author{
Roderick P.W. WILliAMs ${ }^{1 *}$, Lynette D’ATH ${ }^{1}$, Bogdan ZISU $^{2}$ \\ ${ }^{1}$ Food Science Australia, Werribee Laboratory, 671 Sneydes Rd, Werribee, Victoria 3030, Australia \\ ${ }^{2}$ Dairy Innovation Australia, 671 Sneydes Rd, Werribee, Victoria 3030, Australia
}

\begin{abstract}
Although the inherent heat stability and the processes leading to the heat-induced coagulation of milk and reconstituted milk powders have been studied extensively, the processes that lead to heat-induced heat stability are less well established. An investigation has been undertaken into the effects of standardization with milk permeate or lactose and the heat-stabilization of milk powders. Standardized and unstandardized milk powders were produced in spring and autumn to determine seasonal effects on their heat stability. Other standardized powders were produced using a range of preheat treatments $\left(85^{\circ} \mathrm{C} / 1800 \mathrm{~s}, 120^{\circ} \mathrm{C} / 120 \mathrm{~s}\right.$, and $\left.140{ }^{\circ} \mathrm{C} / 5 \mathrm{~s}\right)$ to evaluate the effects of preheat treatment and standardization on the heat stability of milk powders. Micelle size and the soluble aggregates formed during the preheat treatment were characterized by a combination of size-exclusion chromatography and SDS-PAGE. The heat stability of the powders was evaluated in a bench-scale model of retorted recombined evaporated milk manufacture. As has been generally accepted, the heat stability may be mediated by the way in which the milk responds to the preheat treatment given during milk powder manufacture. However, we have found that causing the denaturation of the whey proteins in itself, as is indicated by analytical measures such as the whey protein nitrogen index (WPNI) is not sufficient to impart heat stability. Our work suggests that milks with good heat stability are achieved by heating to give a low WPNI and a balance of moderately sized soluble aggregates and a decrease in the proportion of smaller micelles. The formation of these aggregates is influenced by the heating regime applied and varies at different times of year.
\end{abstract}

heat stability / milk protein aggregation / micellar integrity

\begin{abstract}
摘要 - 奶粉生产过程中热诱导蛋白凝聚体的热稳定性。关于牛奶固有的热稳定性和使牛 奶和还原奶粉热诱导的加工过程已被广泛地研究, 但是对热诱导引起的热稳定性问题却研究 的非常有限。本文研究了经牛奶超滤透过液和乳糖标准化的奶粉的热稳定性。对春季和秋 季的标准化和未标准化的牛奶测定了季节对其热稳定性的影响。对其他标准化的奶粉则采 用了一系列预热处理工艺 $\left(85^{\circ} \mathrm{C} / 1800 \mathrm{~s} 、 120^{\circ} \mathrm{C} / 120 \mathrm{~s}\right.$ 和 $\left.140^{\circ} \mathrm{C} / 5 \mathrm{~s}\right)$ 来评价预热处理和标准 化对奶粉热稳定性的影响。采用体积排阻色谱和 SDS-PAGE 分析了预热处理过程中酪蛋白 胶束的大小和可溶性凝聚物的形成, 并评价了实验室方法生产乳粉的热稳定性。普遍认为, 乳粉生产过程中的预热处理可以调解乳粉的热稳定性; 然而, 根据本研究对处理过程中乳清 蛋白氮溶指数 (WPNI) 的测定, 发现乳清蛋白的变性并不能充分揭示热稳定性。因此, 试验 结果表明热致使牛奶具有较低 WPNI 和适当大小的可溶性凝聚物, 以及较低比例的小酪蛋白 胶束, 这些特性使牛奶具有较好的热稳定性。而这些凝聚物的形成则显著地受热处理方式和 季节的影响。
\end{abstract}

热稳定性 / 乳蛋白的凝聚 / 胶束的完整性

*Corresponding author (通讯作者): roderick.williams@csiro.au 


\begin{abstract}
Résumé - Rôle de l'agrégation des protéines dans la stabilité thermique thermo-induite au cours de la fabrication de poudre de lait. Bien que la stabilité thermique inhérente et les processus conduisant à la coagulation thermo-induite du lait et des poudres de lait reconstituées aient été largement étudiés, les processus qui conduisent à la stabilité thermique thermo-induite sont moins bien établis. Une étude a été entreprise concernant les effets de la standardisation avec du perméat de lait ou du lactose et la stabilisation thermique des poudres de lait. Des poudres de lait, standardisé et non standardisé, ont été produites au printemps et en automne pour déterminer l'effet saison sur leur stabilité thermique. D'autres poudres standardisées ont été produites en appliquant différents prétraitements thermiques $\left(85^{\circ} \mathrm{C} / 1800 \mathrm{~s}, 120^{\circ} \mathrm{C} / 120 \mathrm{~s}\right.$ et $\left.140^{\circ} \mathrm{C} / 5 \mathrm{~s}\right)$ pour évaluer les effets du prétraitement et de la standardisation sur la stabilité thermique des poudres de lait. La taille des micelles et les agrégats solubles formés au cours du prétraitement thermique ont été caractérisés en combinant chromatographie d'exclusion de taille et électrophorèse SDS-PAGE. La stabilité thermique des poudres était évaluée à l'aide d'un modèle simulant à l'échelle de la paillasse la fabrication de lait en poudre recombiné. On considère en général que la stabilité thermique dépend de la façon avec laquelle le lait répond au prétraitement thermique appliqué au cours de la fabrication de poudre. Cependant, nous avons trouvé que la dénaturation des protéines de lactosérum, comme indiquée par des mesures analytiques tel que l'indice d'azote des protéines de lactosérum (WPNI), n'est pas en soi un critère suffisant pour dire qu'il y a stabilité thermique. Notre travail suggère que des laits de bonne stabilité thermique s'obtiennent par chauffage donnant un WPNI bas et un équilibre entre agrégats solubles de taille modérée et une diminution de la proportion des plus petites micelles. La formation de ces agrégats est influencée par le chauffage appliqué et varie au cours des périodes de l'année.
\end{abstract}

stabilité thermique / agrégation des protéines laitières / micelle

\section{INTRODUCTION}

The effect of heat in causing the aggregation of milk proteins into various particles has been extensively studied. Pre-conditioning milk by preheating or forwarming has been applied to improve the heat stability of milk for many years, with papers being published as early as 1929 [16]. More recent investigations have included works by Newstead et al. [26] and Darling [15]. There has also been a growing interest in the formation and structure of milk protein aggregates in heated milks [17, 18, 22, 32, 33, 38, 39]. These investigations have generally been directed towards understanding the importance of these aggregates on the formation of acid induced gels and although Corredig and Dalgleish [11] hinted that variation in the composition of heat induced soluble aggregates may be related to the effects of preheating, their influence on heat stability has not yet been described. Estimates of the size of these aggregates range between $10 \mathrm{~nm}$ and $40 \mathrm{~nm}$ in diameter $[18,32]$ and that could out-number the micelles by at least 10 to 1 . They are potentially very significant contributors to the physical properties of milk.

Previous studies have shown that the aggregates are chiefly comprised of the major whey proteins $\beta$-lactoglobulin and $\alpha$-lactalbumin but may also contain some caseins $[18,22]$. Their formation is therefore likely to be linked not only to the process through which the whey proteins interact with each other, but also to the availability of caseins which are largely organized into micelles. The availability of caseins to interact with whey proteins will also be governed by the integrity of the casein micelles, and their response to heating.

Standardization of milk through the addition of milk permeates or lactose is also a growing practice within the limits specified under the Codex Standard for Milk Powders and Cream Powder [10]. Altering the environment of the milk proteins may also influence both the heat stability of standardized milk powders and the 
formation of soluble aggregates through effects on either protein denaturation or micellar integrity. In addition, milk production systems which are predominantly pasture based, as occurs in Australia, can also be subject to seasonal effects which can affect the heat stability of milk $[6,40]$ and it is not known how these seasonal effects interact with standardization practices. The aim of the following work was to investigate the effects of standardization on both heat stability, soluble aggregate formation, and the effects of seasonal variation.

Experiments were designed to address the effects of standardization, a range of different preheat treatments, and differences in season on the mechanism of heatinduced heat stability.

\section{MATERIALS AND METHODS}

\subsection{Manufacture of skim milk powders}

Skim milk was obtained from Tatura Milk Industries (Tatura, Australia) and processed into either high-heat skim milk or standardized high-heat skim milk powders at Food Science Australia, Werribee. Analytical grade lactose monohydrate was obtained from Chem Supply Pty Ltd (Gillman, South Australia). Milk permeate was obtained by ultrafiltering a portion of the skim milk at $50{ }^{\circ} \mathrm{C}$ using an $10 \mathrm{~m}^{2}$ ultrafiltration membrane (10 000 MWCO, Koch Australia Pty Ltd, Parramatta, Australia).

Three trials were conducted. Trials 1 and 2 were conducted in the spring of 2005: trial 1 investigated standardization with lactose and occurred in September 2005 while trial 2, investigating standardization with permeate occurred in November 2005. Trial 3 investigating the use of both lactose and permeate was conducted in May 2006 (southern autumn).

Milk was received, skimmed and the concentrations of protein and solids were determined using FTIR equipment (Lactoscope FTIR model FT 2.2, Delta Instruments, Drachten, The Netherlands). Milks were standardized with permeate or lactose as required. For standardization with lactose, the lactose was first dissolved in water at $50 \mathrm{~g} \cdot \mathrm{kg}^{-1}$ at room temperature. Preheating of the milks at $120{ }^{\circ} \mathrm{C} / 120 \mathrm{~s}$ or $140{ }^{\circ} \mathrm{C} / 5 \mathrm{~s}$ was performed using a pilot scale indirect tubular UHT plant [21]. Heating at $85{ }^{\circ} \mathrm{C} / 1800 \mathrm{~s}$ was performed using a tubular heat exchanger. Following preheating milks were evaporated to approximately $450 \mathrm{~g} \cdot \mathrm{kg}^{-1}$ total solids (Swept Surface Thin Film evaporator APV Baker Pty Ltd, Springvale, Australia, $45^{\circ} \mathrm{C}-55^{\circ} \mathrm{C}$, approximately $45 \mathrm{~min}$ ), then dried as described previously [5]. The $\mathrm{pH}$ of all milks was between $\mathrm{pH} 6.7$ and 6.8 and was not adjusted before preheating. The standardization and preheat conditions for each of the milk powders produced are shown in Table I.

\subsection{Heat stability testing in model recombined evaporated milk manufacturing}

For bench scale simulation of recombined evaporated milk manufacture (REM) a method based on that of Kieseker and Aitken [24] was adopted. Initial skim milk concentrates were prepared by reconstituting milk powder in distilled water at $45^{\circ} \mathrm{C}$ with continual mixing. The recombined skim milk concentrates were combined with molten anhydrous milk fat, homogenized at $45^{\circ} \mathrm{C}$ using the homogenizer unit from a Foss milkotester having four homogenizing stages equivalent to a treatment of approximately $14 \mathrm{MPa}$ [24], and then cooled to $25^{\circ} \mathrm{C}$.

Portions of the homogenized concentrates were transferred into screw-capped stainless steel tubes and adjusted with water, $\mathrm{HCl}$ solution, or $\mathrm{NaOH}$ solution $(1 \mathrm{~mL}$ total addition) to achieve a range of $\mathrm{pH}$ 


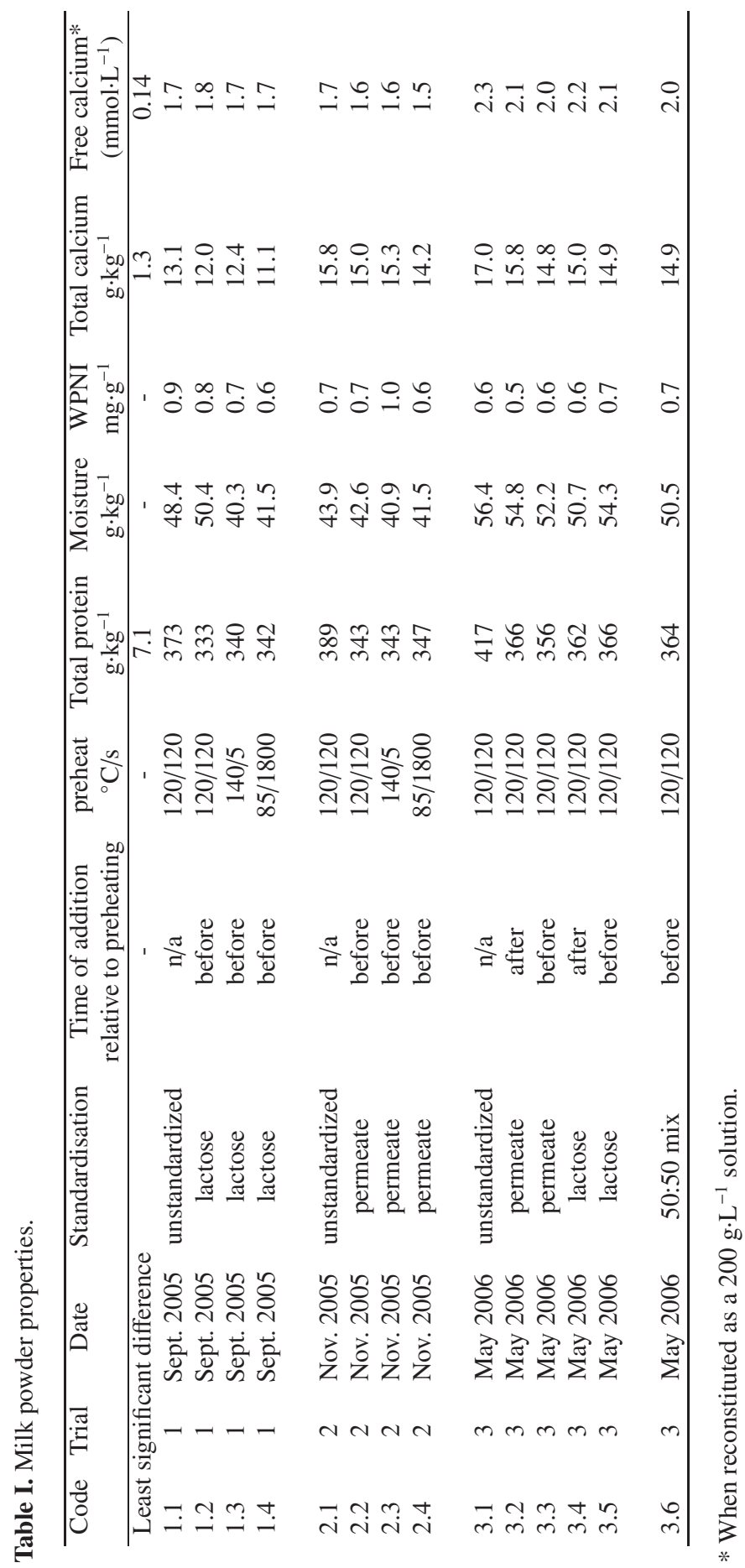


values. The tubes were capped securely and immersed in a boiling water bath for 5 min then transferred to a glycerol bath at $120^{\circ} \mathrm{C}$. Samples were rocked continuously for the first $70 \mathrm{~s}$ then rocked for $30 \mathrm{~s}$ at each 4 min interval during heating. After a total of $13 \mathrm{~min}$ in the glycerol bath, the samples were transferred to a $25{ }^{\circ} \mathrm{C}$ water bath and rocked continuously for $2.5 \mathrm{~min}$ and then allowed to equilibrate at $25^{\circ} \mathrm{C}$ over $1 \mathrm{~h}$.

Following cooling the contents of the tubes were inspected and the viscosities of sterilized samples, which appeared liquid and homogeneous were determined at room temperature using a Brookfield DV-II viscometer fitted with a UL adaptor (Brookfield Engineering Laboratories Inc., Stoughton, MA, USA). A spindle speed of $12 \mathrm{rpm}$ was used. In this test milks are considered "heat stable" if they have a viscosity of $18 \mathrm{mPa} \cdot \mathrm{s}$ or less following heating with an optimum viscosity of 10 to $15 \mathrm{mPa} \cdot \mathrm{s}$ [24]. For industrial robustness it is also considered desirable that the milk be stable at its natural $\mathrm{pH}$ and at least $0.1 \mathrm{pH}$ units above and below the natural $\mathrm{pH}$.

\subsection{Size exclusion chromatography}

All size exclusion data are presented in terms of the partition coefficient (Kav) of each peak where $\mathrm{Kav}=\left(\mathrm{V}_{\mathrm{e}}-\mathrm{V}_{\mathrm{o}}\right) /\left(\mathrm{V}_{\mathrm{t}}-\mathrm{V}_{\mathrm{o}}\right)$, and $\mathrm{V}_{\mathrm{e}}$ is the elution volume of the peak, $\mathrm{V}_{\mathrm{o}}$ is the void volume of the column, and $\mathrm{V}_{\mathrm{t}}$ is the total volume of the column.

\subsubsection{Micellar particles}

The distributions of micelle-sized particles in each of the milks (after preheating but before concentration and drying) were examined by size exclusion chromatography (SEC) on S-1000. A column (1.6 cm dia $\times 98 \mathrm{~cm}$ long) of Sephacryl S-1000SF (cat. 17-0476-01, lot 304180,
Amersham Bioscience Pty Ltd, Baulkham Hills, NSW, Australia) was prepared according to the manufacturers instructions. Samples $(0.5 \mathrm{~mL})$ of milks were applied directly to the column and eluted with a buffer system of $50 \mathrm{mmol} \cdot \mathrm{L}^{-1} \mathrm{NaCl}$, $20 \mathrm{mmol} \cdot \mathrm{L}^{-1}$ Tris, $3 \mathrm{mmol} \cdot \mathrm{L}^{-1} \mathrm{CaCl}_{2}$, $0.2 \mathrm{~g} \cdot \mathrm{kg}^{-1} \mathrm{NaN}_{3} \mathrm{pH} 6.7$ at $0.5 \mathrm{~mL} \cdot \mathrm{min}^{-1}$. This buffer system was selected as having approximately the same $\mathrm{pH}$, ionic strength, and calcium content as milk serum. The column was run on a Pharmacia FPLC system (Amersham Bioscience Pty Ltd) using a LKB 2238 Uvicord SII detector at $280 \mathrm{~nm}$ and 0.05 absorbance units full scale (AUFS).

This separation media partitions the particles and macromolecules in milk into five basic fractions: peak 1 eluting at the void volume $\left(\mathrm{V}_{0}, \mathrm{Kav}=0\right)$ of the column which represents large micelles and possibly aggregates of micelles. Peak 2 represents smaller micelles in a broad peak eluting at Kav of approximately 0.25. Peak 3 (Kav 0.75) being serum proteins, and peak 4 (Kav 0.9), smaller peptides and peak $5(\operatorname{Kav}=1)$ which has typically been attributed to small aromatic molecules [18]. The positions of each of the peaks are indicated in Figure 1.

\subsubsection{Soluble aggregates}

The formation of soluble aggregates in the reconstituted milk powders, was investigated by centrifugation and SEC on S-500 following the method of Guyomarc'h et al. [18]. Milk powders were reconstituted in sodium azide solution $\left(0.2 \mathrm{~g} \cdot \mathrm{kg}^{-1}\right)$ at $100 \mathrm{~g}$ powder $\cdot \mathrm{kg}^{-1}$ solution and allowed to rehydrate at room temperature for 16 to $18 \mathrm{~h}$ (overnight). They were then centrifuged at $33000 \times g$ for $60 \mathrm{~min}$ (Beckman L90 centrifuge, $55.2 \mathrm{Ti}$ rotor $20000 \mathrm{rpm}$, Beckman Coulter Australia Pty Ltd, Gladesville, NSW, Australia) to separate soluble 


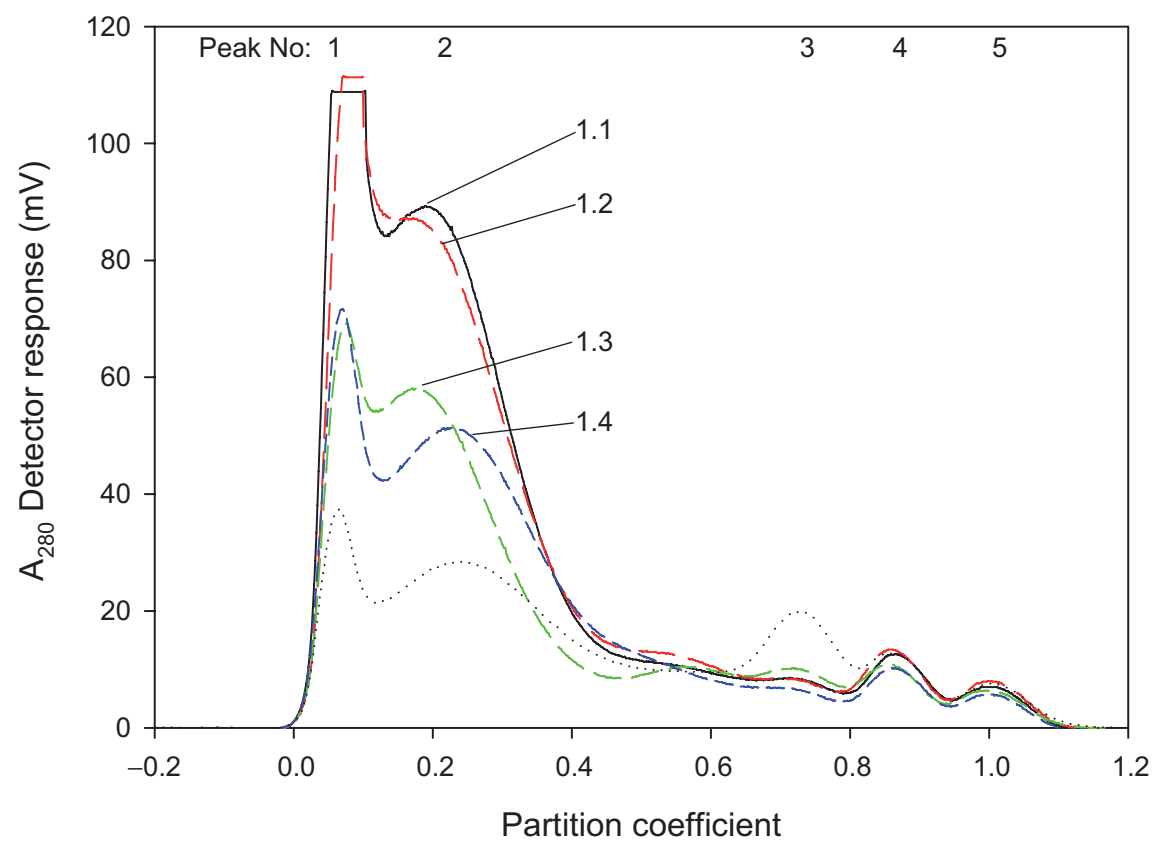

Figure 1. SEC (S-1000) of milks used to produce lactose standardized milk powders in trial 1. Peaks numbered as described in text.

- Sample 1.1, unstandardized milk, preheated $\left(120^{\circ} \mathrm{C} / 120 \mathrm{~s}\right)$.

- Sample 1.2, preheated at $120^{\circ} \mathrm{C} / 120 \mathrm{~s}$.

- - - Sample 1.3, preheated at $140{ }^{\circ} \mathrm{C} / 5 \mathrm{~s}$.

---=- Sample 1.4, preheated at $85^{\circ} \mathrm{C} / 1800 \mathrm{~s}$.

......... Unheated milk.

and micellar phases. Supernatants were collected by pouring off everything but the firm pellet. The supernatants were prepared for chromatography by dilution $1: 1$ in elution buffer then centrifugation in $1.5 \mathrm{~mL}$ microcentrifuge tubes (Sigma 201 M centrifuge, Crown Scientific Pty Ltd, Wantirna South, Vic., Australia) at $14000 \mathrm{rpm}$ for $10 \mathrm{~min}$ to remove gross particulates. Aliquots of each prepared supernatant $(0.5 \mathrm{~mL})$ were applied to a column $(1.6 \mathrm{~cm}$ dia $\times 90 \mathrm{~cm}$ long $)$ of Sephacryl S-500HR (cat. 17-0613-01, lot QC-11351, Amersham Bioscience Pty Ltd), and eluted with a buffer of $100 \mathrm{mmol} \cdot \mathrm{L}^{-1}$ Tris, $50 \mathrm{mmol} \cdot \mathrm{L}^{-1} \mathrm{NaCl}$, $0.2 \mathrm{~g} \cdot \mathrm{kg}^{-1} \mathrm{NaN}_{3} \mathrm{pH} 7.0$ at a flow rate of
$0.5 \mathrm{~mL} \cdot \mathrm{min}^{-1}$. The column was run on a Pharmacia FPLC system using a LKB 2238 Uvicord SII detector at $280 \mathrm{~nm}$ and 0.05 AUFS.

This separation media partitions the aggregates and proteins in the milk serum into five peaks. Peak 1 eluting at the void volume $\left(\mathrm{V}_{0}, \mathrm{Kav}=0\right)$ is considered to contain a mixture of very large aggregates, non-sedimentable micelles, or small fat globules. Peak 2 (Kav 0.1 to 0.5 ) occurs only in heated milks, it represents the soluble aggregates. Peak 3 elutes at a Kav $\sim 0.65$ represents discrete proteins, typically $\beta$-lactoglobulin and $\alpha$-lactalbumin. Peak 3 is the most prominent peak in unheated milks. Peaks 4 and 5 at Kav values 


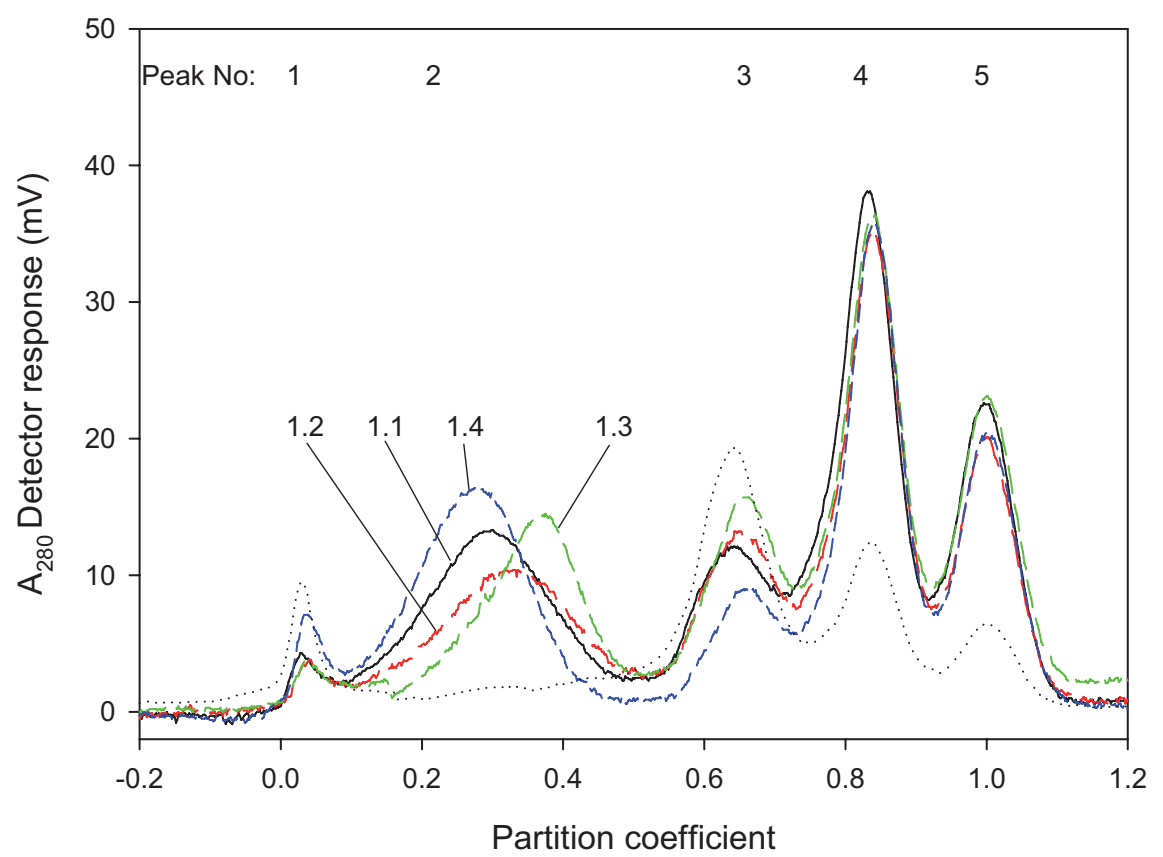

Figure 2. SEC (S-500) of supernatant fractions from reconstituted, lactose standardized, milk powders produced in trial 1 . Peaks numbered as described in text.

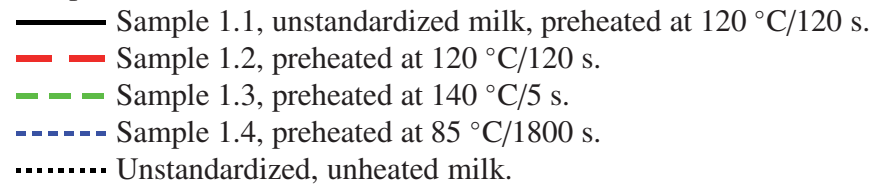

of approximately 0.9 and 1.0 respectively are small peptides and dialyzable aromatic molecules [18]. These peaks are indicated on Figure 2.

To obtain sufficient soluble aggregate material for compositional analysis of the aggregate fraction a large scale SEC system was adopted. Milk powders were reconstituted and centrifuged and supernatants collected as described above. The supernatants were combined then concentrated by ultrafiltration using a stirred ultrafiltration cell (model 402) fitted with a YM10 membrane (76 $\mathrm{mm}$ diameter) (Millipore Australia Pty Ltd, North Ryde, NSW, Australia). The combined supernatants were concentrated approximately three times. A sample $(50 \mathrm{~mL})$ of each concentrated supernatant was applied to a column of Sephacryl S-500HR $(5.0 \mathrm{~cm}$ dia $\times 90 \mathrm{~cm}$ long), and eluted with a buffer of $100 \mathrm{mmol} \cdot \mathrm{L}^{-1}$ ammonium bicarbonate $\mathrm{pH} 7.0$ at a flow rate of $3.0 \mathrm{~mL} \cdot \mathrm{min}^{-1}$. The column was run using an LKB 2152 HPLC controller, LKB 2150 HPLC pump and a LKB 2151 variable wavelength monitor at $280 \mathrm{~nm}$ set at 2.56 AUFS. The run time was $1000 \mathrm{~min}$. Fractions $(5 \mathrm{~min} / 15 \mathrm{~mL})$ were collected between 270 and 470 min using a LKB Superac 2211 fraction collector. Fractions were pooled in groups of three and evaporated to dryness using a Genevac HT4 Series X concentrator (Genevac Ltd, Ipswich, UK). Fractions of 
interest were redissolved in distilled water $(5 \mathrm{~mL})$ and re-dried twice to remove any residual ammonium bicarbonate. Samples were stored dry at $-20^{\circ} \mathrm{C}$ until analysis by gel electrophoresis.

\subsection{Polyacrylamide gel electrophoresis}

Polyacrylamide gel electrophoresis of the aggregate fractions was performed under denaturing conditions on pre-cast $120 \mathrm{~g} \cdot \mathrm{kg}^{-1}$ Acrylamide gels $\left(\mathrm{NuPage}^{\circledR}\right.$ Novex Bis-Tris gels, Invitrogen Australia Pty Ltd, Mt Waverley, Vic., Australia). Each of the dried soluble aggregate fraction samples was dissolved in a dissociating buffer $\left(6 \mathrm{~mol} \cdot \mathrm{L}^{-1}\right.$ urea, $5 \mathrm{mmol} \cdot \mathrm{L}^{-1}$ trisodium citrate, $1 \mathrm{mmol} \cdot \mathrm{L}^{-1}$ dithiothreitol/pH 8.0) then diluted in water. Samples 1.1 to 2.4 were diluted $1 / 10$, samples 3.2 to 3.6 were diluted $1 / 5$ and sample 3.1 was diluted $1 / 4$. A sample of the diluted material $(25 \mu \mathrm{L})$ was then mixed with NuPage ${ }^{\circledR}$ LDS sample buffer, reducing agents and deionised water with an effective 1:1 further dilution. Samples of molecular weight marker proteins, and reconstituted freeze-dried pasteurised milk were also prepared for comparison and peak identification. All samples were denatured and reduced by incubating at $70{ }^{\circ} \mathrm{C}$ for $10 \mathrm{~min}$. Aliquots $(10 \mu \mathrm{L})$ of the denatured and reduced samples were applied to the gels and run at $125 \mathrm{~V}$ for $10 \mathrm{~min}$ then at $180 \mathrm{~V}$ for a further $50 \mathrm{~min}$. The running buffer was NuPage ${ }^{\circledR}$ MES SDS buffer with the composition: $50 \mathrm{mmol} \cdot \mathrm{L}^{-1}$ MES, $50 \mathrm{mmol} \cdot \mathrm{L}^{-1}$ Tris base, $1 \mathrm{~g} \cdot \mathrm{kg}^{-1}$ SDS, $1 \mathrm{mmol} \cdot \mathrm{L}^{-1}$ EDTA, pH 7.3. Following electrophoresis, the gels were stained using an Invitrogen SimplyBlue ${ }^{\mathrm{TM}}$ staining kit following the manufacturer's instructions. The stained gels were then photographed and the photographs analyzed using Scion Image software (obtained online at http://www.scioncorp.com/). Plots of pixel density vs. migration distance were obtained and integrated to obtain an indication of the relative contributions of the major proteins in the soluble aggregate fraction. The results of the area analyses are shown in Tables II(a) and II(b).

\subsection{Analytical}

Total protein in milk powders was determined using a LECO FP-2000 nitrogen analyzer (Leco Australia Pty Ltd, Castle Hill, NSW, Australia) according to the manufacturer's instructions using EDTA as standard. Moisture was determined by drying to constant weight in an oven at $102{ }^{\circ} \mathrm{C}$.

The $\mathrm{pH}$ of samples was determined using a PHM 93 reference $\mathrm{pH}$ meter fitted with a PHC2401 electrode (Radiometer Pacific, Blackburn, Vic., Australia). The free calcium ion activity of samples was determined using a $\mathrm{Ca}^{2+}$ specific electrode (Radiometer F2112) following the method of Augustin and Clarke [7]. Milk powders were reconstituted in water at $200 \mathrm{~g} \cdot \mathrm{kg}^{-1}$ total solids, warmed to $45^{\circ} \mathrm{C}$ and homogenized as described above for the laboratory scale REM model. The milks were reequilibrated to room temperature for the calcium ion measurement.

Whey protein nitrogen index was determined at a commercial laboratory; Dairy Technical Services Ltd (Kensington, Vic., Australia). Where possible, the statistical significance of the analytical precision is indicated by the calculation of least significant differences between means using ANOVA at $95 \%$ confidence intervals.

\section{RESULTS AND DISCUSSION}

Experiments were designed to compare the effects of standardization with either permeate or lactose, the role of different preheat treatments, and two different times 
Table II(a). Relative areas (\%) of regions from image analysis of Figure 9. Because of the potentially large uncertainty regarding the baseline corrections the areas of region 1 have not been included in the calculations.

\begin{tabular}{lcccc}
\hline \multirow{2}{*}{ Sample } & Region 1 & Region 2 & Region 3 & Region 4 \\
\cline { 2 - 5 } & $\alpha_{\text {S2 } 2 \text {-casein }}$ & $\beta$ and א-caseins & $\beta$-lactoglobulin & $\alpha$-lactalbumin \\
\hline 1.1 & - & 29 & 42 & 29 \\
1.2 & - & 39 & 42 & 19 \\
1.3 & - & 44 & 38 & 18 \\
1.4 & - & 37 & 42 & 21 \\
2.1 & - & 41 & 37 & 22 \\
2.2 & - & 42 & 38 & 20 \\
2.3 & - & 42 & 38 & 20 \\
2.4 & - & 38 & 41 & 21 \\
\hline
\end{tabular}

Table II(b). Relative areas (\%) of regions from image analysis of Figure 10. Because of the potentially large uncertainty regarding the baseline corrections the areas of region 1 have not been included in the calculations.

\begin{tabular}{lcccc}
\hline \multirow{2}{*}{ Sample } & Region 1 & Region 2 & Region 3 & Region 4 \\
\cline { 2 - 5 } & $\alpha_{\text {S2 }}$-casein & $\beta$ and k-caseins & $\beta$-lactoglobulin & $\alpha$-lactalbumin \\
\hline 3.1 & - & 29 & 51 & 21 \\
3.2 & - & 43 & 40 & 17 \\
3.3 & - & 43 & 42 & 15 \\
3.4 & - & 42 & 41 & 18 \\
3.5 & - & 41 & 43 & 16 \\
3.6 & - & 42 & 40 & 18 \\
\hline
\end{tabular}

of year. Because of the issues of day-today variation in milk properties, it was desirable to complete each trial with a single batch of milk. Because of a desire to limit the risk of contamination, and to minimize changes in the milk which may occur during storage, trials were conducted as quickly as possible within the constraints of the equipment available. For these reasons, all options could not be tested in each of the trials which were undertaken. However, the effects of standardization, heat treatment, and season, and the influence of aggregation on heat stability can be considered separately.

\subsection{Effects of standardization}

The effects of standardization alone are best considered by comparing the control and standardized samples, which received the same heat treatment $\left(120{ }^{\circ} \mathrm{C} / 120 \mathrm{~s}\right)$ in each of the three trials. These were samples 1.1 (control) and 1.2 (lactose standardized) in trial 1, samples 2.1 (control) and 2.2 (permeate standardized) in trial 2 , and samples 3.1 (control) and 3.3 (permeate standardized) or 3.1 (control) and 3.5 (lactose standardized) in trial 3.

\subsubsection{Powder characteristics}

As shown in Table I, standardization had a moderate effect on the powder characteristics, depending on the level of protein in the milk. As intended, the primary change was a reduction in protein content, and this also was reflected in a reduction on the WPNI values for the standardized powders compared to their respective 


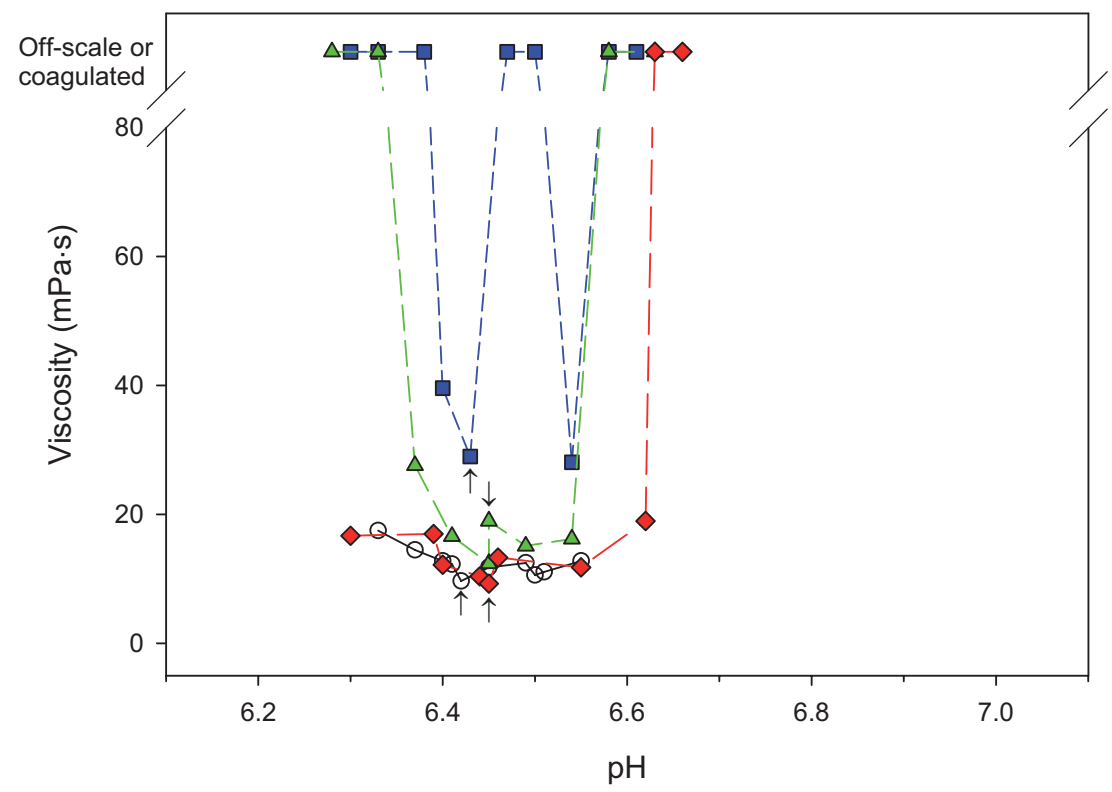

Figure 3. Data obtained in the model REM test for milk powders from trial 1.

O Sample 1.1, unstandardized milk powder heated at $120^{\circ} \mathrm{C} / 120 \mathrm{~s}$.

$\checkmark$ Sample 1.2, milk powder standardized with lactose preheated at $120^{\circ} \mathrm{C} / 120 \mathrm{~s}$.

$\triangle$ Sample 1.3, milk powder standardized with lactose preheated at $140{ }^{\circ} \mathrm{C} / 5 \mathrm{~s}$.

Sample 1.4, milk powder standardized with lactose preheated at $85^{\circ} \mathrm{C} / 1800 \mathrm{~s}$.

Arrows indicate unadjusted $\mathrm{pH}$.

controls. Standardization generally caused a reduction in the total calcium contents of the powders.

\subsubsection{Heat stability}

The data are presented in Figures 3, 4 and 5 . In the trials conducted in the spring ( 1 and 2 ) it is notable that the base milks (1.1 and 2.1) had good heat stability (i.e. viscosities less than $18 \mathrm{mPa} \cdot \mathrm{s}$ ) over a wide range of $\mathrm{pH}$. Standardization with lactose (1.2) caused a little change in heat stability while standardization with permeate (2.2) gave slightly higher viscosities compared to their respective controls, indicating a slight reduction in heat stability, but the results were still within the acceptable range. In trial 3 the control milk (3.1) was only marginally stable at its natural $\mathrm{pH}$ and would be considered unreliable for use in retorted applications as an acceptable viscosity $(<18 \mathrm{mPa} \cdot \mathrm{s})$ was not obtained at the natural $\mathrm{pH}$ and also within at least $0.1 \mathrm{pH}$ units above and below the natural $\mathrm{pH}$ [24]. When the milk was standardized with permeate (3.3) or lactose (3.5) the heat stability improved, with lower viscosity readings, and an increase in the range of $\mathrm{pH}$ above and below the natural $\mathrm{pH}$ over which the lower viscosities were recorded. Although the data from these three trials are limited, it suggests that there is little effect of standardization on heat stability when the milk is inherently heat stable and a relatively low level of standardization is required to achieve the permitted minimum protein content. When the milk is naturally less stable, and more standardization 


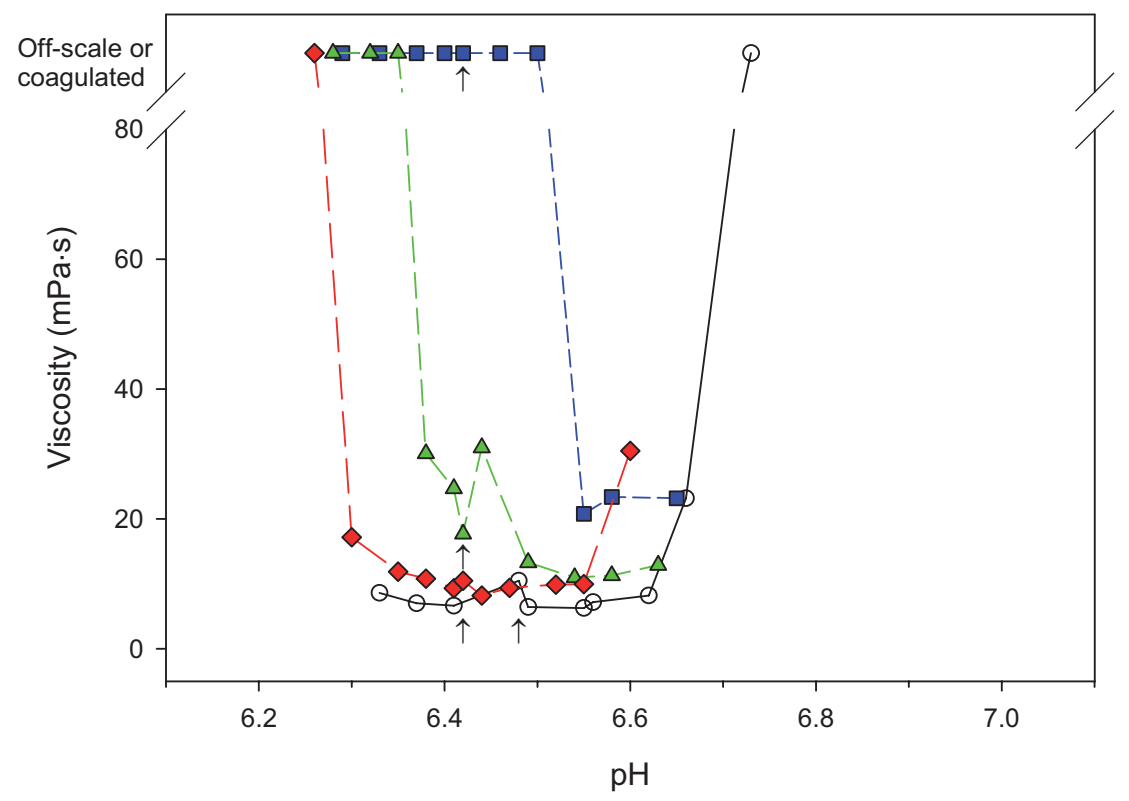

Figure 4. Data obtained in the model REM test for milk powders from trial 2. Arrows indicate unadjusted $\mathrm{pH}$.

O Sample 2.1, unstandardized milk powder heated at $120^{\circ} \mathrm{C} / 120 \mathrm{~s}$.

$\checkmark$ Sample 2.2, milk powder standardized with permeate preheated at $120^{\circ} \mathrm{C} / 120 \mathrm{~s}$.

$\triangle$ Sample 2.3, milk powder standardized with permeate preheated at $140{ }^{\circ} \mathrm{C} / 5 \mathrm{~s}$.

$\square$ Sample 2.4, milk powder standardized with permeate preheated at $85^{\circ} \mathrm{C} / 1800 \mathrm{~s}$.

is required, the effects are greater such as the improvement in heat stability seen in trial 3.

\subsubsection{Investigation of aggregation states by SEC}

The aggregation states created during milk powder manufacture were examined by size exclusion chromatography. Two separation media were used. The whole sample was analyzed on Sephacryl S-1000 to evaluate changes in micellar sized particles while the non-micellar phase of the milks was analyzed using Sephacryl S-500 after centrifugation to separate the micellar and non-micellar phases.

\subsubsection{Change in the size distributions of micellar particles}

Figure 1 shows the distribution of particles in the milks used to produce the powders in trial 1 . The unheated milk showed the characteristic pattern of five peaks, the first two representing excluded material and smaller micelles, and the remaining three peaks being serum proteins, peptides and small aromatic molecules. On heating, the serum proteins peak was reduced and there was a shift in the position of the second (small micelle) peak to earlier elution times indicating an increase in micelle size. There was also an apparent increase in the amount of material eluting in peaks 1 and 2 . Given that the later peaks (4 and 5), which are not heat sensitive, 


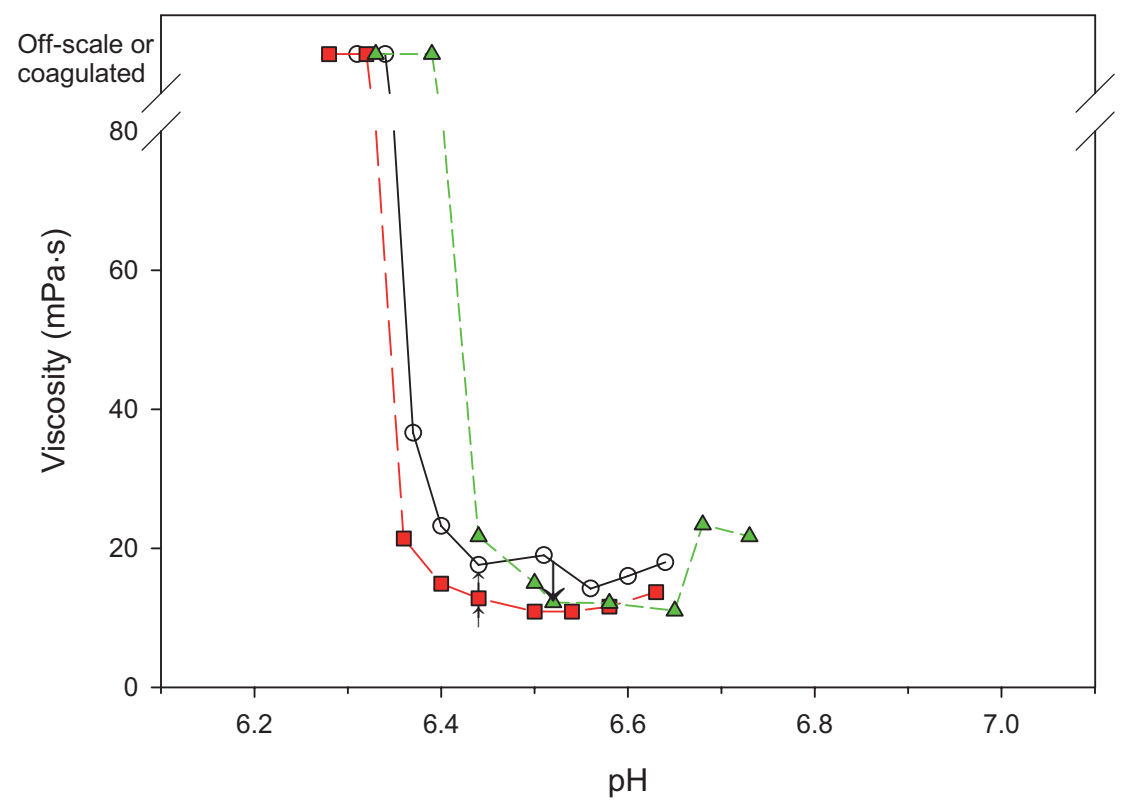

Figure 5. Data obtained in the model REM test for control and standardized milk powders from trial 3. Arrows indicate unadjusted $\mathrm{pH}$.

O Sample 3.1, unstandardized milk powder $\left(120^{\circ} \mathrm{C} / 120 \mathrm{~s}\right.$ preheat $)$.

- Sample 3.3, milk powder standardized with permeate $\left(120^{\circ} \mathrm{C} / 120 \mathrm{~s}\right.$ preheat).

$\Delta$ Sample 3.5 , milk powder standardized with lactose $\left(120^{\circ} \mathrm{C} / 120 \mathrm{~s}\right.$ preheat $)$.

act as a form of internal standard, we can identify that similar amounts of each sample were applied to the column. The apparent increase in the $\mathrm{A}_{280}$ response of the peaks 1 and 2 may be due to an increase in the molar extinction coefficient of the protein that may occur when proteins are denatured and unfolded, perhaps through increasing the exposure of the relevant aromatic amino acids [25]. Also, as these are large particles which may have appreciable light-scattering potential, changes in their size will influence the degree of light scattering which will result in a change in the apparent absorbance. For these reasons, quantification of the material from these traces is difficult. However, there is much useful qualitative information from the relative elution positions and the proportions of the material that elute in peaks 1 and 2 .
There were generally small differences in the distributions of particles between standardized and unstandardized milks. In trial 1, Figure 1, comparing samples 1.1 and 1.2 , the pattern shown by the lactose standardized milk (1.2) suggests that preheating caused a shift to larger particle sizes than those present in the unstandardized preheated milk (1.1). The shift is in the order of a change in partition coefficient of approximately 0.05 . Earlier work with this column (data not shown) suggests that this could represent a shift of $10-20 \mathrm{~nm}$ in the diameters of the particles represented by this peak. In trial 3, Figure 6 , the lactose standardized milk (3.5) had a more distinct population of smaller particles compared to either the permeate standardized (3.3) or unstandardized milks (3.1) which were similar to each other. 


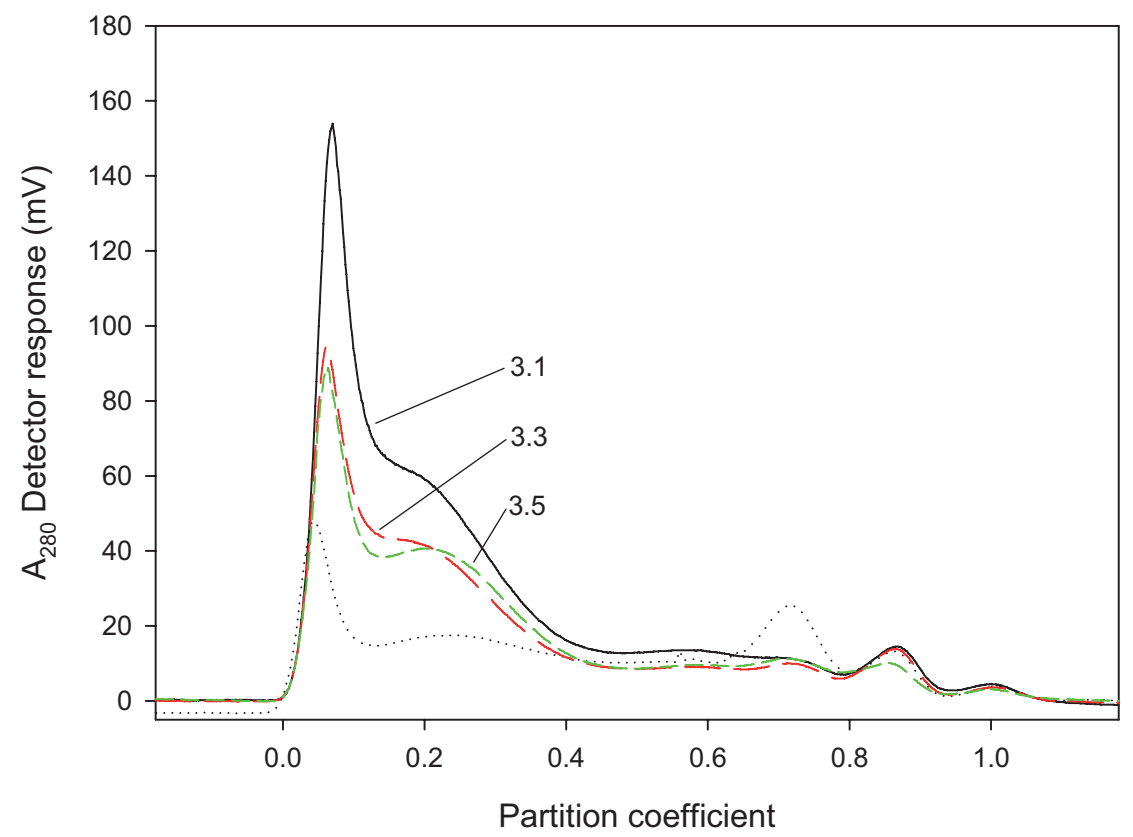

Figure 6. SEC (S-1000) of milks used to produce milk powders in trial 3.

- Sample 3.1, unstandardized milk, preheated $\left(120^{\circ} \mathrm{C} / 120 \mathrm{~s}\right)$.

- Sample 3.3, milk standardized with permeate, then preheated $\left(120^{\circ} \mathrm{C} / 120 \mathrm{~s}\right)$.

- - - Sample 3.5, milk standardized with lactose, then preheated $\left(120^{\circ} \mathrm{C} / 120 \mathrm{~s}\right)$.

$==-=-=$ Unheated milk.

This suggests that the standardization with lactose or permeate can have some effect on the aggregation of particles caused by preheating but the effect is influenced by other factors. The primary difference between permeate, and lactose standardization is that the use of lactose will have a greater effect on the mineral composition of the milks. In this case, it appears that reducing the mineral content through lactose standardization has reduced the degree of aggregation. This has parallels with earlier work [6] where heat stability could be improved by reducing calcium ion activity.

\subsubsection{Distributions of soluble aggregates}

Figure 2 shows the profiles for the milk powders produced in trial 1. Comparing the heated and unheated unstandardized samples shows the characteristic pattern of the disappearance of serum proteins (peak 3) accompanied by the appearance of soluble aggregates (peak 2) which occurs when milks are heated. Heating does not influence either peaks 4 or 5 .

There were no clear patterns in the effects of standardization on the formation of soluble aggregates. The elution patterns shown in Figure 2 show that in trial 1, standardization with lactose and preheating at $120{ }^{\circ} \mathrm{C} / 120 \mathrm{~s}$ caused the production of slightly smaller soluble aggregates than occurred in the milk which was given the same preheat treatment without standardization while in trial 2, Figure 7, the soluble aggregates in the standardized and unstandardized milks were the same size when given the same $120^{\circ} \mathrm{C} / 120$ s preheat 


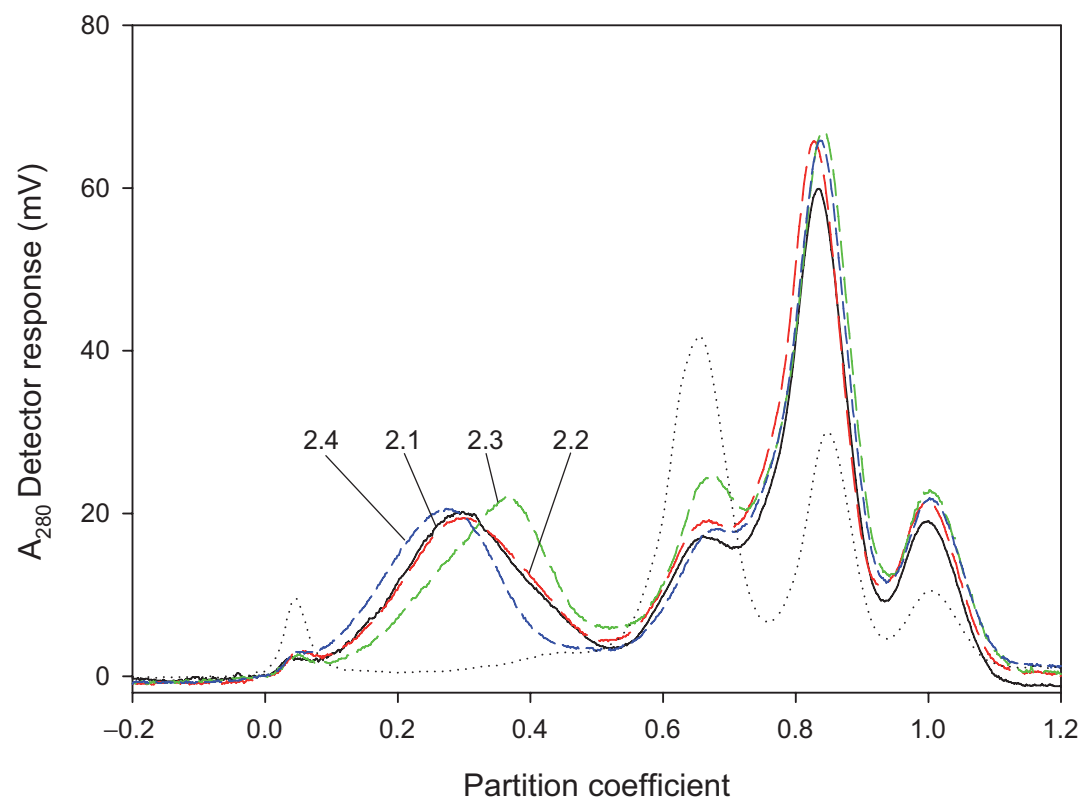

Figure 7. SEC (S-500) of supernatant fractions from reconstituted permeate standardized milk powders produced in trial 2.

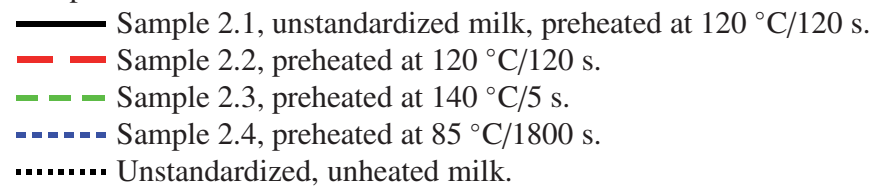

treatment. In trial 3, Figure 8, standardized and unstandardized milks were similar in that little soluble aggregate material was created in any of the milks. This will be discussed below in relation to the seasonal effects.

\subsubsection{Soluble aggregate composition}

Using the large scale chromatographic processes described above a fraction corresponding to the peak of the soluble aggregate material was collected and analyzed for protein composition by polyacrylamide gel electrophoresis. Images of the gels are given in Figures 9 and 10. The relative areas of the peak intensities are given in Tables II(a) and II(b). Because of the involved nature of obtaining the peak fraction, no attempt has been made to compare the levels of the proteins between trials. As seen from the lanes representing the skim milk samples, the analysis allows a clear separation of the main whey proteins $\beta$-lactoglobulin and $\alpha$-lactalbumin from the caseins, and some of the minor whey proteins such as bovine serum albumin (BSA). The caseins migrate as a close group consistent with the similarity of their molecular weights. The bands have been assigned to the different casein species by comparison with typical previous examinations of milks on $120 \mathrm{~g} \cdot \mathrm{kg}^{-1}$ SDS-PAGE [3, 17, 34].

The data suggests that the aggregate fractions generally contain the major whey proteins $\alpha$-lactalbumin and 


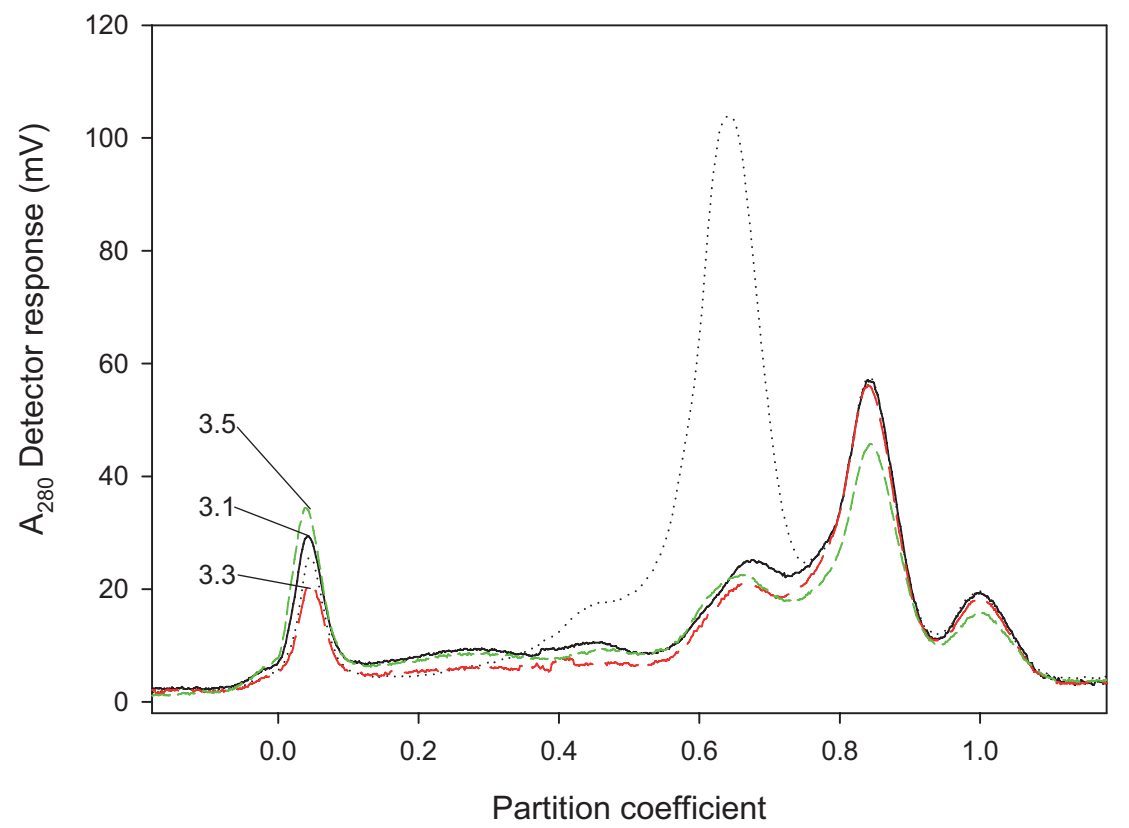

Figure 8. SEC (S-500) of supernatants from reconstituted milk powders from trial 3.

\footnotetext{
Sample 3.1 , unstandardized milk, preheated at $120^{\circ} \mathrm{C} / 120 \mathrm{~s}$.

- Sample 3.3, milk standardized with permeate, then preheated at $120^{\circ} \mathrm{C} / 120 \mathrm{~s}$.

- - - Sample 3.5, milk standardized with lactose, then preheated at $120^{\circ} \mathrm{C} / 120 \mathrm{~s}$.

. Unheated milk.
}

$\beta$-lactoglobulin, and $\kappa$ - and $\beta$-caseins. Bovine serum albumin and other large whey proteins are also present. A band representing the largest casein, $\alpha_{\mathrm{S} 2}$, is present on SDS-PAGE in some of the samples, notably 1.1 and 1.4 , and in 2.1 and 2.4. The qualitative compositional analyses of the soluble aggregate fractions are generally in line with previous reports [17, 18, 22, 32]. These studies consider that the primary constituents of the aggregates are $\beta$-lactoglobulin, $\alpha$-lactalbumin and $\kappa$ casein. In some cases they have identified small amounts of $\alpha$ - and $\beta$-caseins in some of their samples. As in the work reported here, $\alpha_{S_{1}}{ }^{-}$and $\beta$-caseins are presumably associated with the soluble aggregate fraction through non-covalent interactions as neither contains any cysteine residues through which covalent S-S bonds may be formed. In contrast, $\alpha_{\mathrm{S} 2}$-casein contains two cysteine residues and may therefore be involved in covalent bonding in the aggregates. As $\alpha_{\mathrm{S} 2}$-casein is suggested to be the most difficult casein to dissociate from the micelles [18], its appearance in the soluble aggregate fraction presumably indicates a more extensive dissociation or rearrangement of the micelles.

For investigations into the effects of standardization with lactose, comparisons should be made between samples 1.1 and 1.2 , or 3.1 and 3.5 which are unstandardized/lactose standardized pairs given the same $120{ }^{\circ} \mathrm{C} / 120 \mathrm{~s}$ heat treatment from trials 1 and 3 respectively. The most noticeable feature between samples 1.1 and 1.2 is that the unstandardized sample (1.1) has the identifiable $\alpha_{\mathrm{S} 2}$ casein band which is not present in the 


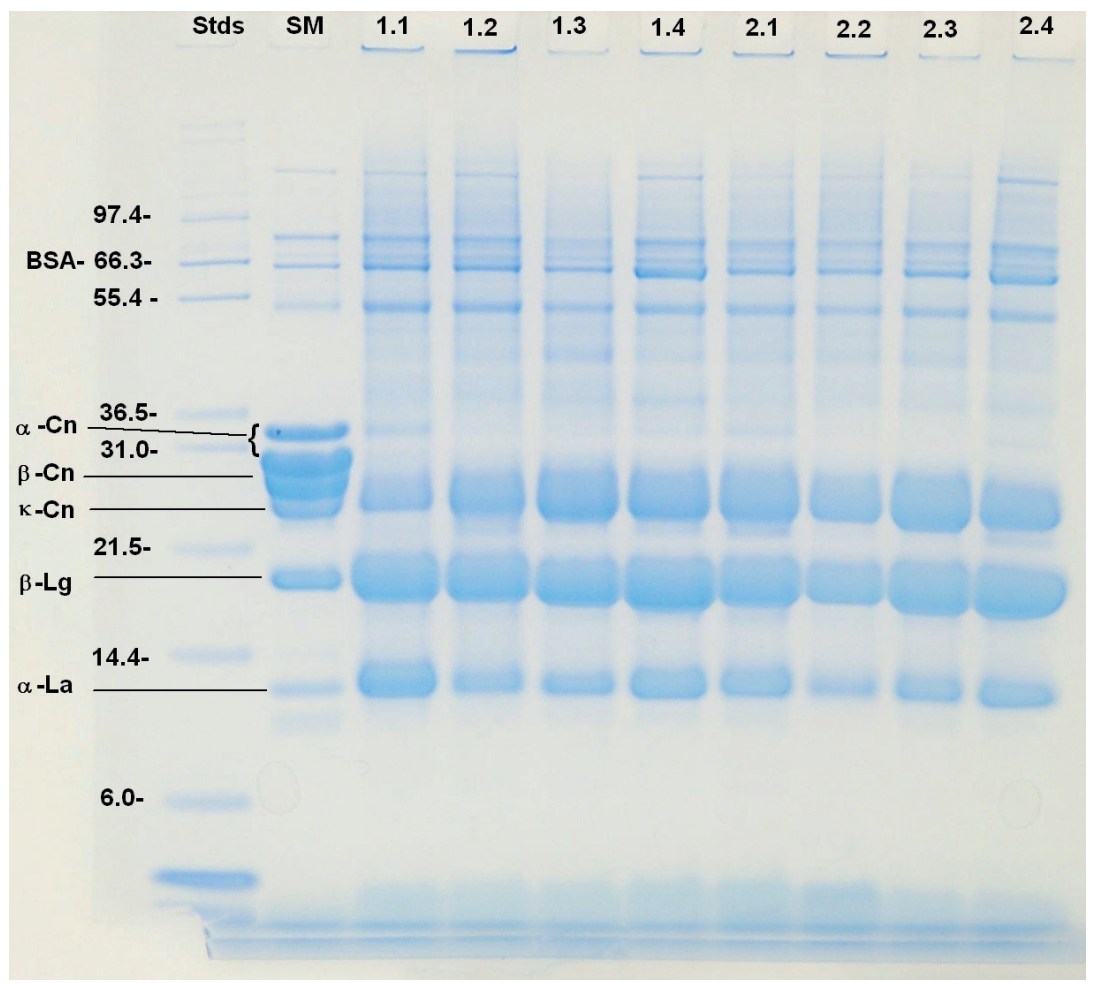

Figure 9. SDS-PAGE (reduced) of soluble aggregate fractions of reconstituted milk powders produced in trials 1 and 2.

Stds: Molecular weight standards of the masses indicated.

SM: Sample of reconstituted freeze dried milk.

Trial 1:

1.1: Unstandardized milk powder, preheated at $120^{\circ} \mathrm{C} / 120 \mathrm{~s}$.

1.2: Lactose standardized milk powder preheated at $120^{\circ} \mathrm{C} / 120 \mathrm{~s}$.

1.3: Lactose standardized milk powder preheated at $140{ }^{\circ} \mathrm{C} / 5 \mathrm{~s}$.

1.4: Lactose standardized milk powder preheated at $85^{\circ} \mathrm{C} / 1800 \mathrm{~s}$.

Trial 2:

1.1: Unstandardized milk powder, preheated at $120^{\circ} \mathrm{C} / 120 \mathrm{~s}$.

1.2: Permeate standardized milk powder preheated at $120^{\circ} \mathrm{C} / 120 \mathrm{~s}$.

1.3: Permeate standardized milk powder preheated at $140^{\circ} \mathrm{C} / 5 \mathrm{~s}$.

1.4: Permeate standardized milk powder preheated at $85^{\circ} \mathrm{C} / 1800 \mathrm{~s}$.

standardized sample. Sample 3.5 has a much higher level of material than sample 3.1 overall, but the $\alpha_{\mathrm{S} 2}$-casein band is not present. A similar pattern occurred for the samples standardized with permeate. Samples 2.1 and 2.2, and 3.1 and 3.3 are unstandardized/permeate standardized pairs from trial 2 and trial 3 respectively which were also given the same $120{ }^{\circ} \mathrm{C} / 120 \mathrm{~s}$ heat treatment. While all of the powders were relatively heat stable (as in the case of the lactose standardized milks), the powders with the more consistent stability were the samples from trial 1 


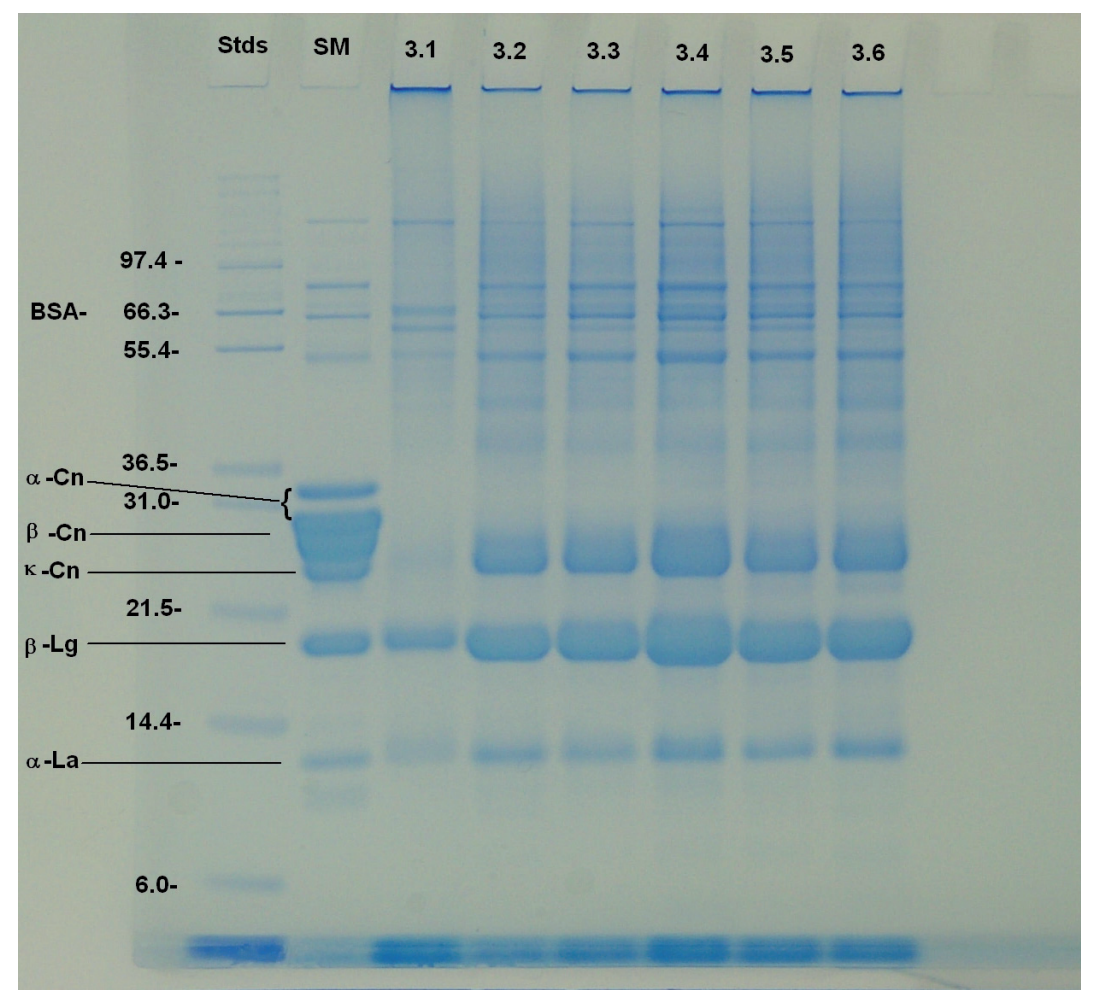

Figure 10. SDS-PAGE (reduced) of soluble aggregate fractions of reconstituted milk powders produced in trial 3.

Stds: Molecular weight standards of the masses indicated.

SM: Sample of reconstituted freeze dried milk.

3.1: Unstandardized, preheated at $120^{\circ} \mathrm{C} / 120 \mathrm{~s}$.

3.2: Preheated at $120^{\circ} \mathrm{C} / 120 \mathrm{~s}$ then standardized with permeate.

3.3: Standardized with permeate then preheated at $120^{\circ} \mathrm{C} / 120 \mathrm{~s}$.

3.4: Preheated at $120^{\circ} \mathrm{C} / 120 \mathrm{~s}$ then standardized with lactose.

3.5: Standardized with lactose then preheated at $120^{\circ} \mathrm{C} / 120 \mathrm{~s}$.

3.6: Standardized with lactose/permeate mix then preheated at $120^{\circ} \mathrm{C} / 120 \mathrm{~s}$.

and 2, particularly samples 1.1 and 2.1, which also had the most clearly identifiable $\alpha_{\mathrm{S} 2}$-casein bands.

Some additional information concerning the effects of standardization on the composition of the soluble aggregates is to compare the aggregates that were heat treated before or after standardization in trial 3. These are samples 3.2 and 3.3 (standardization with permeate) or 3.4 and
3.5 (standardization with lactose). It is noted that the samples that were preheated after standardization, have a slightly higher proportion of $\beta$-lactoglobulin, and lower proportion of $\alpha$-lactalbumin than the matched samples which were heated before standardization (Tab. II(b)).

A pattern of altered protein denaturation in standardized milks is consistent with a higher ratio of sugars to 
proteins providing protection of the protein against denaturation which has been described previously [23]. It has also been reported that added sugars have a greater stabilizing effect on $\beta$-lactoglobulin than on $\alpha$-lactalbumin [9] which could also lead to altered ratios of the two proteins in the aggregates from standardized milks compared to unstandardized milks. However, these studies show the difference between low and much higher levels of lactose. In other work we have seen that there was little practical difference in the denaturation temperatures of $\beta$-lactoglobulin (measured by differential scanning calorimetry) caused by the change in the levels of lactose typical of milk standardization (data not shown). In addition, the temperature used for preheating these milks $\left(120^{\circ} \mathrm{C}\right)$ is far higher than the denaturation temperatures of either of the major whey proteins.

For these reasons it seems most likely that kinetic effects, and possibly the role of casein proteins appear more likely to play a role in influencing the composition of the soluble aggregates than do any alterations of the denaturation temperature caused by standardization.

\subsection{Effects of different preheat treatments}

The effects of different preheating conditions were examined on the standardized milks in trials 1 and 2. Because each trial was made using a different batch of milk, and different standardization agents were used in each, the major comparisons should be made within each trial, rather than between the two trials.

\subsubsection{Powder characteristics}

As shown in Table I, the different preheating conditions had little effect on the characteristics of the powders that were produced. All heat treated powders would be considered 'high heat' according to the ADMI specification of less than $1.5 \mathrm{mg}$ undenatured whey protein per gram of powder [1]. In both trials milks which were preheated at $85{ }^{\circ} \mathrm{C} / 1800 \mathrm{~s}$ had the lowest levels of undenatured whey protein. However, given that all powders were well below the threshold to be considered 'high heat', the small differences are not considered to be particularly significant.

\subsubsection{Heat stability}

The data are presented in Figures 3 and 4 . Both trials show that heat stability is strongly influenced by preheat treatment. Standardized milks given the $120^{\circ} \mathrm{C} / 120 \mathrm{~s}$ treatment were heat-stable over a wide $\mathrm{pH}$ range making them well suited for manufacture in retorted recombined evaporated milk. In both trials the milk powders were less stable when given a preheat treatment of $140{ }^{\circ} \mathrm{C} / 5 \mathrm{~s}$ and were quite unstable when given a preheat treatment of $85^{\circ} \mathrm{C} / 1800 \mathrm{~s}$. It was notable that all milk powders had similar low WPNI values, well below the $1.5 \mathrm{mg} \cdot \mathrm{g}^{-1}$ threshold, but they showed a range of heat stabilities. This reinforces the argument that WPNI alone is not an accurate predictor of milk powder functionality [5] and suggests that there are additional factors which contribute to heatinduced heat stability, not just a low level of undenatured whey protein.

\subsubsection{Investigation of aggregation states by SEC}

The aggregation states created during milk powder manufacture were examined by size exclusion chromatography. Two separation media were used. The whole sample was analyzed on Sephacryl S-1000 to evaluate changes in micellar sized particles while the non-micellar phase of the 


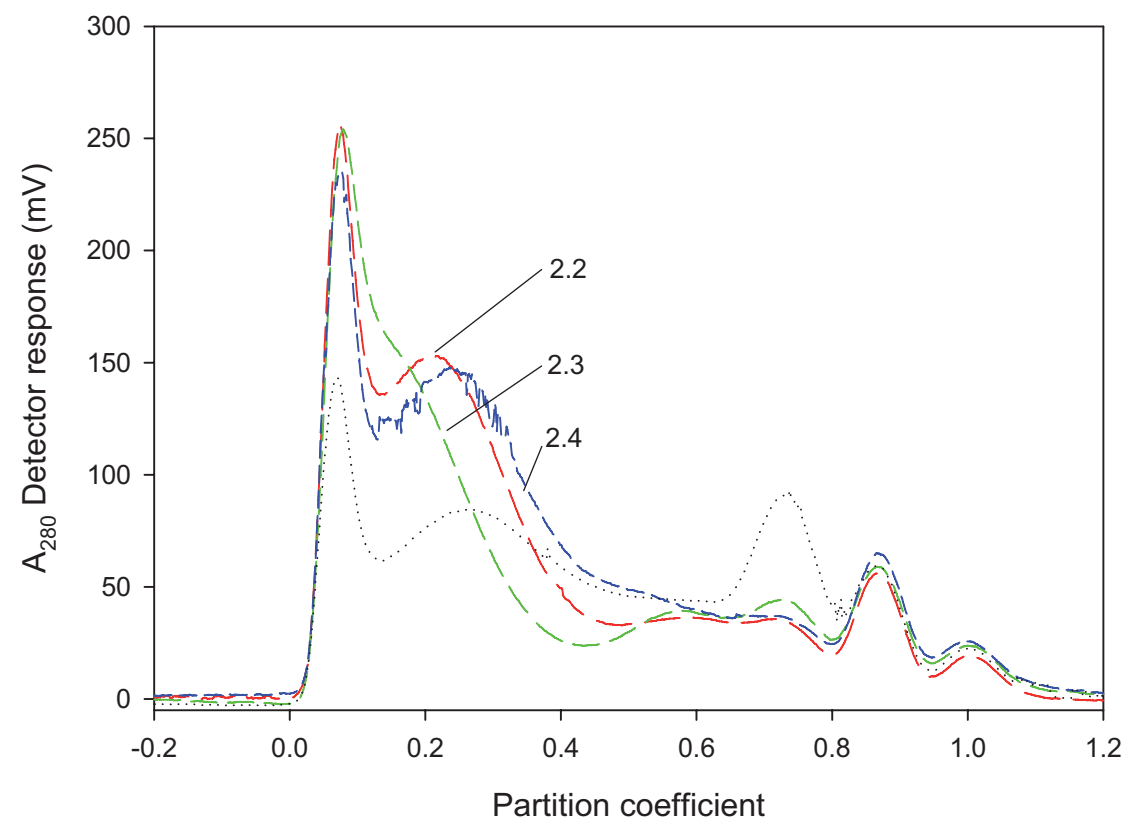

Figure 11. SEC (S-1000) of milks used to produce permeate standardized milk powders in trial 2.

- Sample 2.2, preheated at $120^{\circ} \mathrm{C} / 120 \mathrm{~s}$.

- - - Sample 2.3, preheated at $140{ }^{\circ} \mathrm{C} / 5 \mathrm{~s}$.

$=-=--$ Sample 2.4, preheated at $85{ }^{\circ} \mathrm{C} / 1800 \mathrm{~s}$.

......... Unheated milk.

milks was analyzed using Sephacryl S-500 after centrifugation to separate the micellar and non-micellar phases.

Figures 1 and 11 show the effects of different heat treatments on the distributions of micellar sized particles in preheated standardized milks. In both trials, the milks heated at $85^{\circ} \mathrm{C} / 1800 \mathrm{~s}$ show little change in the position of peak 2 . This suggests that although there was extensive whey protein denaturation, there was little change in micelle size. When heated at $120{ }^{\circ} \mathrm{C}$ and $140{ }^{\circ} \mathrm{C}$ the respective peaks eluted slightly earlier, indicating an increase in size. The extent of these changes varied between trials and heat treatments. In trial 1, heating at $120{ }^{\circ} \mathrm{C} / 120 \mathrm{~s}$ produced slightly larger particles than heating at $140{ }^{\circ} \mathrm{C} / 5 \mathrm{~s}$ while in trial 2 , heating at $140{ }^{\circ} \mathrm{C} / 5 \mathrm{~s}$ produced the larger particles.
The elution patterns in Figures 2 and 7 show the effects of different heat treatments on the sizes of particles in the soluble phases of the milks. Soluble aggregates were created by all heat treatments in both trials. In both trials, heating at $85^{\circ} \mathrm{C} / 1800 \mathrm{~s}$ or $140{ }^{\circ} \mathrm{C} / 5 \mathrm{~s}$ produced the largest and smallest soluble aggregates respectively. Peak 3 represents the discrete soluble protein components and shows a qualitative agreement with the WPNI data in that the milks given the treatment of $85^{\circ} \mathrm{C} / 1800 \mathrm{~s}$ showed both the lowest WPNI and the lowest peak height.

The relationship between the sizes of the micelles and soluble aggregates and preheat treatments is complex. A model for these processes which occur at each of the three preheat conditions used is given in Figure 12. Following the model 


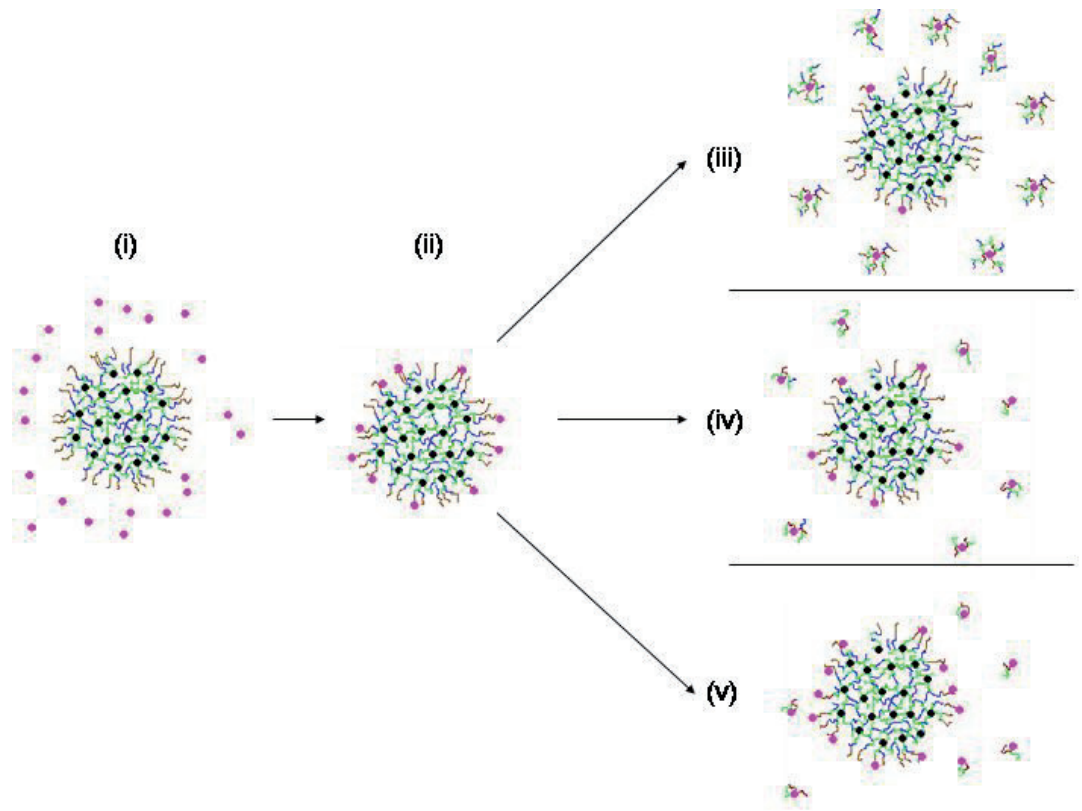

Figure 12. Suggested mechanisms associated with preheat induced aggregation under different preheat conditions.

(i) Milk containing mixture of casein in micelles and whey proteins.

(ii) Preheating initiates aggregation of caseins and whey proteins at the micellar surface.

(iii) $85{ }^{\circ} \mathrm{C} / 1800 \mathrm{~s}$ : Considerable dissociation of the whey protein-casein aggregates from the micellar surface, resulting in minimally changed micelles and large soluble aggregates.

(iv) $120^{\circ} \mathrm{C} / 120 \mathrm{~s}$ : Partial dissociation of the whey protein-casein aggregates from the micellar surface, resulting in micelles with slightly increased sizes and moderately sized aggregates.

(v) $140{ }^{\circ} \mathrm{C} / 5 \mathrm{~s}$ : Minimal dissociation of the whey protein-casein aggregates from the micellar surface, resulting in larger micelles and smaller soluble aggregates.

of Corredig and Dalgleish [12] the interaction between whey proteins and caseins is assumed to take place at the micellar surface and then a degree of dissociation occurs causing the appearance of soluble aggregates. Our data shows that when milk was heated at $85{ }^{\circ} \mathrm{C} / 1800 \mathrm{~s}$ the soluble aggregates were larger and the micelles only increased slightly in size after heating, suggesting that a greater degree of dissociation of the whey protein-casein complexes has occurred. An intermediate situation occurs when milk is heated at $120{ }^{\circ} \mathrm{C} / 120 \mathrm{~s}$ (intermediate sized soluble aggregates, intermediate increase in $\mathrm{mi}-$ celle size). When heated at $140{ }^{\circ} \mathrm{C} / 5 \mathrm{~s}$ the micelles were the largest, and the soluble aggregates smallest, suggesting the lowest level of dissociation of the whey-protein casein complexes. It is interesting to note that each of the different heat treatments cause the creation of discretely differently sized populations of aggregates, not just more or less of the same size aggregate. This also suggests that different aggregation and or dissociation processes are involved at each temperature and time combination. The optimum heat stability is achieved with a heat treatment of $120^{\circ} \mathrm{C} / 120 \mathrm{~s}$ suggesting that a balance of micellar dissociation and soluble aggregate formation is required. 


\subsubsection{Composition of soluble aggregates}

Fractions representing the soluble aggregate components were collected and analyzed by SDS-PAGE to investigate the effects of the different heat treatments on their composition. The gels obtained are shown in Figure 9 and analyses of the band densities are given in Table II(a). As described above, the aggregate fractions generally contain the major whey proteins $\alpha$-lactalbumin and $\beta$-lactoglobulin, and $\kappa-$ and $\beta$-caseins. Bovine serum albumin and other large whey proteins are also present. The general pattern of proteins present in the soluble aggregates in relation to the heat treatment given is consistent across trials 1 and 2 . The main differences between heat treatments appear in the $\alpha_{\mathrm{S} 2}$-casein band. As has been described above, when heat-treated at $120{ }^{\circ} \mathrm{C} / 120 \mathrm{~s}$ both of the unstandardized samples (1.1 and 2.1) show this band while the un standardized samples do not. However, when standardized samples are given a lower temperature/longer time treatment of $85^{\circ} \mathrm{C} / 1800 \mathrm{~s}$, (samples 1.4 and 2.4) the $\alpha_{\mathrm{S} 2}$-casein band is faintly present again. The $\alpha_{\mathrm{S} 2}$-casein band does not appear to be present in the samples given a $140{ }^{\circ} \mathrm{C} / 5 \mathrm{~s}$ preheat treatment. In this respect our data differ from that of Guyomarc'h et al. [18] who found that $\alpha_{\mathrm{S} 2}$-casein was more prevalent in smaller aggregates. In our case, the intermediate sized aggregates $\left(120^{\circ} \mathrm{C} / 120 \mathrm{~s}\right)$ contain the most while the smallest $\left(140{ }^{\circ} \mathrm{C} / 5 \mathrm{~s}\right)$ contain the least.

The key influences on the altered compositions of the soluble aggregates are likely to be the relationship between the times and temperatures of heating, and the kinetics of the release of the various caseins from the micelles. Previous studies have shown that micellar dissociation increases with increasing temperature of heating [2] and with increasing time of heating [35]. Earlier studies have proposed that the order of release of the caseins is in relation to their phospho-serine contents and the loss of these residues during prolonged heating [13] however others have questioned the role of phospho-serine binding of $\kappa$-casein to the micelle [35]. The block copolymer model of Horne [21] also suggests phospho-serine related binding has a less significant role in binding $\kappa$ casein to the micelle and that hydrophobic interactions are mainly responsible.

Different heating regimes also affect the way in which the whey proteins interact with the micelles. An important component of these differences is a change in the denaturation kinetics of the whey proteins which occurs around $90{ }^{\circ} \mathrm{C}$ [14]. Corredig and Dalgleish [11] found that higher temperatures over shorter times caused a change in the ratios of $\alpha$ lactalbumin and $\beta$-lactoglobulin included in the micellar fraction. They predicted that the $\alpha$-lactalbumin to $\beta$-lactoglobulin ratio would be higher when a lower temperature and longer time is used for preheating. It is interesting to note their comment that this may account for the reason that high temperatures for shorter times are preferred for preheating in industry. Higher temperature/shorter time regimes such as $120{ }^{\circ} \mathrm{C} / 120 \mathrm{~s}$, have also been found to give better heat stability [26] which is also borne out by the work presented here.

\subsection{Seasonal effects}

Trials were undertaken in September and November (the southern spring) and May (the southern autumn). These times were selected as they were traditionally associated with times of good and poor heat stability respectively [8]. The simplest seasonal comparisons may be made by comparing samples 1.1, 2.1 and 3.1. These were all unstandardized milks given the same $120^{\circ} \mathrm{C} / 120 \mathrm{~s}$ heat treatment. 


\subsubsection{Powder characteristics}

The most notable compositional difference between the unstandardized milk powders was that the protein and free calcium ion contents of the milk used in trial 3 (May) was significantly higher than the powders collected in trials 1 and 2 (September and November respectively). The high protein content is consistent with the milks being from cows predominantly in late lactation when protein content of the milk rises. The high protein content is of practical significance in relation to standardization in that a greater level of addition of the standardizing agents was required to lower the protein content in trial 3 compared to the earlier trials. The free calcium ion activity and the total calcium content of the powders in trial 3 was also significantly higher than that seen in trials 1 and 2, but not outside the expected range [20]. All of the three unstandardized milk powders had low WPNI values consistent with their high heat treatment during manufacture.

\subsubsection{Heat stability}

As shown in Figures 3, 4 and 5, there was a difference in heat stability between the unstandardized milk powders produced in trials 1 and 2 (September, November) and trial 3 (May) with a poorer heat stability occurring in May (southern autumn). This agrees with earlier studies [8] that have demonstrated a strong seasonal effect on heat stability in REM manufacture where milks produced in the spring were more stable than milks collected in autumn. In the current work the differences are not as pronounced as seen previously. An important factor is that the earlier work [8] was based on a preheat treatment of $85^{\circ} \mathrm{C} / 1800 \mathrm{~s}$ and as discussed above, the current work has shown that preheat conditions such as $120^{\circ} \mathrm{C} / 120 \mathrm{~s}$ stabilize milks that are not stabilized by $85{ }^{\circ} \mathrm{C} / 1800 \mathrm{~s}$ treatments.

\subsubsection{Investigation of aggregation states by SEC}

Seasonal differences in the distributions of micellar sized particles, and their response to heating can be made by comparing the traces presented in Figures 1 and 6. If the unheated milks are compared, the shape of the elution profiles suggest that in the spring (Fig. 1) there was a more even distribution between the large and small micelle peaks, and a clear valley between them. In the autumn (Fig. 6), the large micelle peak is more dominant suggesting a higher proportion of larger micelles. Previously, reduced heat stability for milk with larger micelles has been reported by O'Connell and Fox [28] who produced milks with different micellar sizes by differential centrifugation. In this case, the natural increase in micelle size may account for some of the reduced heat stability observed in this work, and traditionally associated with milks from late autumn in Australia [8]. The spring and autumn milks also respond differently to preheating. In spring (Fig. 1) the chromatograms for preheated milks retain some separation between the small and large micelle peaks, while in autumn, the small micelle peak disappears to form a shoulder on the side of the large micelle peak. This suggests that preheating causes the autumn milks to form a larger proportion of larger particles.

Seasonal differences in the distributions of soluble aggregates may be compared by looking at the profiles for the unstandardized milks in Figures 2, 7 and 8. The striking difference between the spring and autumn milks is that the autumn milks do not show an appreciable level of soluble aggregates. While the lack of soluble aggregates could indicate an inadequate heat treatment in trial 3 , the reduction in the 
serum proteins peak at $\mathrm{Kav} \sim 0.65$ and the WPNI data indicate that the whey proteins were modified by heating. What seems most likely is that in trial 3 , the serum proteins were formed into larger aggregates, or were bound to the micelles, and sedimented with the micelle fraction during the centrifugation to separate the serum and micellar fractions.

A range of researchers have described changes in the distribution of proteins between the micellar and serum phases of milk under the influence of heat. Significant influences on the distribution are the $\mathrm{pH}$ [3] and time and temperature of heating [29]. There may also be some question over what constitutes both serum and micellar proteins due to the wide range of methods that have been used to separate the micellar from soluble proteins. Recently, Donato and Dalgleish [17], using techniques similar to the present work, have demonstrated that the presence and size of the soluble aggregate material is highly dependant on $\mathrm{pH}$ with little material being present when milk was heated $\left(90{ }^{\circ} \mathrm{C} / 600 \mathrm{~s}\right)$ at $\mathrm{pH} 6.3$ but increased levels of soluble aggregate material as the $\mathrm{pH}$ was increased. The size of the soluble aggregate material also decreased as the $\mathrm{pH}$ increased. Although in our experiments all preheating was conducted with the milk at its unadjusted $\mathrm{pH}$ (6.7 to 6.8), we do not know how the $\mathrm{pH}$ of the milk alters during the heating process. A seasonal difference in the formation of soluble aggregates (and heat stability) may therefore reflect a seasonal difference in the way in which the $\mathrm{pH}$ of the milk responds to heating.

\subsubsection{Soluble aggregate composition}

Seasonal comparisons may be made by comparing samples 1.1, 2.1 and 3.1. These are all unstandardized milks given the same $120{ }^{\circ} \mathrm{C} / 120 \mathrm{~s}$ heat treatment, manufactured in each of the three trials. The patterns shown by samples 1.1 and 2.1 are consistent. Both have the strongest bands for $\alpha_{\mathrm{S} 2}$-casein while sample 3.1 does not show the presence of any $\alpha_{\mathrm{S} 2}$-casein. In general, there is also a trend to higher $\alpha$-lactalbumin to $\beta$-lactoglobulin ratios in the samples obtained in the spring (samples 1.1 and 2.1, Tab. II(a)) compared to autumn (sample 3.1, Tab. II(b)) which are times of year traditionally associated with better and poorer heat stability respectively [8].

The reproducibility of the pattern observed in the spring gives weight to the hypothesis that the heat-induced heat stability of milk is linked to the level of micellar dissociation and or the degree to which caseins (other than $\kappa$-casein) are incorporated into soluble aggregates. However, it does not appear that this is a marker for heat stability in itself as appearance of $\alpha_{\mathrm{S} 2}$-casein is observed in some of the most and least stable milks.

Other factors must also be involved. Comparison of the unstandardized milks from trials 1, 2 and 3 shows a clear pattern of seasonal difference between the milks collected in the spring (trials 1 and 2) and autumn (trial 3). Milks from the spring have smaller micelles, which experience a smaller growth in size on preheating compared to the milk collected in autumn. The milks collected in spring show the presence of soluble aggregates while the milks collected in autumn do not. This suggests that in autumn the serum proteins have been formed into larger aggregates, or have been bound to the micelles, and have been sedimented with the micelle fraction. A model for these processes is given in Figure 13. Again, the interaction between whey proteins and caseins is assumed to take place at the micellar surface and then a degree of dissociation occurs. In the spring when the milk was more heat stable, it is suggested that there is a higher level of aggregate detachment from the micelles, leading to only a moderate 

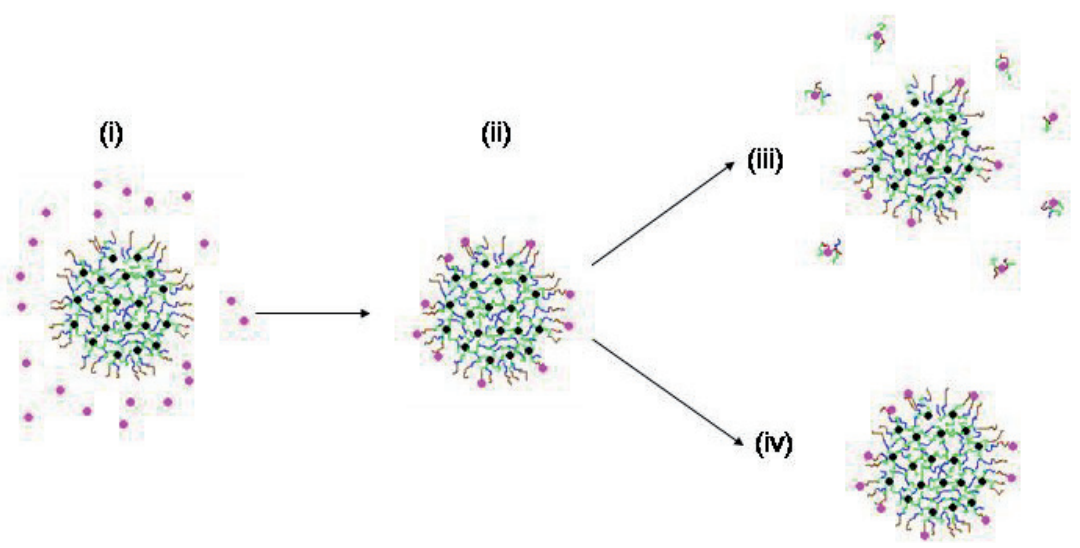

Figure 13. Suggested mechanisms associated with preheat induced aggregation in spring or autumn milks.

(i) Milk containing mixture of casein in micelles and whey proteins.

(ii) Preheating initiates aggregation of caseins and whey proteins at the micellar surface.

(iii) In spring: Partial dissociation of the whey protein-casein aggregates from the micellar surface, resulting in moderately sized aggregates and micelles with slightly increased sizes.

(iv) In autumn: Minimal aggregate dissociation of the whey protein-casein aggregates from the micellar surface, resulting in larger micelles and minimal levels of soluble aggregates.

increase in the size of the micelles and the presence of soluble aggregates. In the autumn the milk was less heat stable and following preheat treatment, the micelles were larger, there was little soluble aggregate formation suggesting greater micellar integrity. At this stage it is not known what causes this seasonal variation. One aspect is the initial size of micelles as the milks from the autumn have larger sizes and larger micelle sizes have been associated with poorer heat stability [28]. Another important factor is the balance of salts. In these experiments the less heat stable milk powders have higher free calcium ion activities when reconstituted. This is in agreement with earlier reports that showed that a seasonal increase in the ratio of calcium to orthophosphate could be correlated with a reduction in heat stability [30]. Lowering free calcium ion activity through the addition of calcium sequestering agents has also been shown to improve the heat stability of preheated milk powders [6]. In our experiments we have seen that additional factors linked to the stability of the micelles and the aggregation states of the proteins may also be involved. It seems likely that the free calcium ion activity exerts an influence on the formation of soluble aggregates, and heat-induced heat stability, but these concepts need to be tested further.

\section{CONCLUSION}

Analysis of the soluble aggregates formed during the preheating step in milk powder manufacture has demonstrated that there are differences in size and composition influenced by the conditions of preheat treatment, the alteration of the milk composition by standardization, and to the time of year at which the milk was produced. This work has shown that different preheat times and temperatures, while giving roughly similar extents of whey protein denaturation when determined by chemical tests such as WPNI, give different 
arrangements of the aggregated proteins and micellar dissociation.

This work also allows us to suggest a variation in the protein aggregation and dissociation mechanism which may be associated with the difference in heat stability traditionally associated with milks from spring and autumn in Australia [8]. The most striking difference is the appearance of $\alpha_{\mathrm{S} 2}$-casein in the aggregates in the samples which had the highest heat stability in a model REM system.

The occurrence of $\alpha_{\mathrm{S}_{2} \text {-casein in soluble }}$ aggregates is a contested issue. The work of Noh et al. [27] demonstrated that $\alpha_{\mathrm{S} 2}$ casein can react with $\alpha$-lactalbumin and $\beta$-lactoglobulin but its reactivity was low. Guyomarc'h et al. [18] found some $\alpha_{\mathrm{S} 2}$ casein in their aggregates but found that it tended to be more prevalent in the smaller aggregates and suggested that it may play a role in limiting their size. However, they also express concern that the presence of the $\alpha_{\mathrm{S} 2}$-casein was an artifact of their analytical system.

Other investigations into the composition and structure of the serum-based aggregates are both more recent and less numerous. Unfortunately many different techniques have been used to separate the micellar and serum phases. Centrifugation is the most common but many different conditions have been used, ranging from $175000 \times \mathrm{g} / 60 \mathrm{~min}$ to $19200 \times g / 240 \min [2,4,11,17,18,22,29$, $32,33,35-37,41]$. Other researchers have rejected the use of centrifugation on the basis of being too harsh and likely to cause micellar disintegration and have used treatment with rennet to precipitate the micelle fraction instead [38].

The range of centrifugation conditions used in the various studies present potential difficulties in comparing the studies. In general all of the studies are relying on the centrifuge to remove the micellar material. However they are also expecting that non-micellar material will not be sedimented. The sedimentation of molecules and particles in the centrifuge relies on a large number of factors including the gravitational force which promotes sedimentation and the buoyant forces and frictional forces which retard it [31]. All of these forces are dependent on the experimental conditions. The buoyant and frictional forces are subject to variation with factors such as the density and viscosity of the solvent and the size and shape of the sedimenting particles. These factors will not be common across different systems and to some extent may not be fully predictable. In our experiments, we have followed the rationale of Guyomarc' $h$ et al. [18] using the tandem approach of combining mild centrifuge conditions with chromatography which is essentially a sieving technique to sort the particles according to their size. While more involved than the use of centrifugation alone, this approach has the benefit of positively selecting for the aggregated particles, and should avoid including either large micellar aggregates, or un-aggregated proteins. It also allows differentiation between aggregated and non-aggregated soluble proteins.

In our experiments the presence of $\alpha_{\mathrm{S}^{-}}$ casein in the soluble aggregates suggests a more extensive dissociation or rearrangement of the micelles as it is generally considered the most strongly attached component of the micelles [18]. Given constant preheat conditions standardization appears to reduce the appearance of $\alpha_{\mathrm{S} 2}$-casein in the aggregates. This would suggest that either the lower protein content, or increased lactose content assists in stabilizing the micelles.

Standardization also appears to alter the proportions of $\alpha$-lactalbumin and $\beta$-lactoglobulin in the aggregates. Standardization appears to lead to a lower proportion of $\alpha$-lactalbumin, but there is also a seasonal effect. It seems most likely that these differences are related to kinetic 
effects, or possibly the role of casein proteins in influencing the composition of the soluble aggregates than any alteration of denaturation temperatures.

These observations point to the importance of the preheat treatment step to establish the correct low WPNI and a balance of moderately sized soluble aggregates combined with a decrease in the proportion of smaller micelles to create milks with good heat stability. The differences in the compositions of these aggregates suggest that the processes of heat-induced micellar dissociation and protein aggregation play an important role in the development of heatinduced heat stability.

Acknowledgements: We acknowledge financial support from Dairy Innovation Australia. Drs P. Kelly and J. Kelly from the TeagascMoorepark Food Research Centre, Moorepark, Fermoy, Co. Cork, Ireland are thanked for useful discussions. The assistance of R. Smith, A. Lawrence, W. Beattie and D. Unthank in producing pilot scale milk powders, and $\mathrm{S}$. Sui in running SDS-PAGE is gratefully acknowledged.

\section{REFERENCES}

[1] American Dry Milk Institute, Standards for grades of dry milks including methods of analysis, Bulletin 916, American Dry Milk Institute, Chicago (1971) p. 9.

[2] Anema S.G., Klostermeyer H., The effect of $\mathrm{pH}$ and heat treatments on the $\kappa$-casein content and the $\zeta$ potential of the particles in reconstituted skim milk, Milchwissenschaft 52 (1997) 217-222.

[3] Anema S.G., Li Y., Further studies on the heat-induced $\mathrm{pH}$ dependent dissociation of casein from the micelles in reconstituted skim milk, Lebensm.-Wiss. Technol. 33 (2000) 335-343.

[4] Anema S., Li Y., Association of denatured whey proteins with casein micelles in heated reconstituted skim milk and its effect on casein micelle size, J. Dairy Res. 70 (2003) 73-83.

[5] Augustin M.A., Ingredients for recombination of dairy products, in Proceedings of the 3rd international symposium on recombined milk \& Milk products, Special issue 9902, Int. Dairy Fed., Brussels, Belgium (1999) pp. 66-70.

[6] Augustin M.A., Clarke P.T., Effects of added salts on the heat stability of recombined concentrated milk, J. Dairy Res. 57 (1990) 213226.

[7] Augustin M.A., Clarke P.T., Calcium ion activities of cooled and aged reconstituted recombined milks, J. Dairy Res. 58 (1991) 219-229.

[8] Augustin M.A., Clarke P.T., Greenwood T., The heat stability of recombined evaporated milk made from skim milk powder produced in late autumn and winter, Aust. J. Dairy Technol. 45 (1990) 47-49.

[9] Boye J.I., Alli I., Thermal denaturation of mixtures of $\alpha$-lactalbumin and $\beta$-lactalbumin: A differential scanning calorimetric study, Food Res. Int. 33 (2000) 673-682.

[10] CODEX STAN 207-1999: Codex standard for milk powders and cream powder, viewed on line, 20 March 2007, http://www.codexalimentarius.net/download/ standards/333/CXS_207e.pdf.

[11] Corredig M., Dalgleish D.G., The binding of $\alpha$-lactalbumin and $\beta$-lactoglobulin to casein micelles in milk treated by differing heating systems, Milchwissenschaft 51 (1996) 123126.

[12] Corredig M., Dalgleish D.G., The mechanisms of the heat-induced interaction of whey proteins with casein micelles in milk, Int. Dairy J. 9 (1999) 233-236.

[13] Dalgleish D.G., Pouliot Y., Paquin P., Studies on the heat stability of milk I. Behaviour of divalent cations and phosphate in milk heated in a stainless steel system, J. Dairy Res. 54 (1987) 29-37.

[14] Dannenberg F., Kessler H.-G., Reaction kinetics of the denaturation of whey proteins in milk, J. Food Sci. 53 (1988) 258-263.

[15] Darling D.F., Heat stability of milk, J. Dairy Res. 47 (1980) 199-210.

[16] Deysher E.F., Webb B.H., Holm G.E., The relations of temperature and time of forewarming of milk to the heat stability of its evaporated product, J. Dairy Sci. 12 (1929) 80-89.

[17] Donato L., Dalgleish D.G., Effect of the heating $\mathrm{pH}$ on the qualitative and quantitative compositions of the sera of reconstituted 
skim milks and on the mechanisms of formation of soluble aggregates, J. Agric. Food Chem. 54 (2006) 7804-7811.

[18] Guyomarc'h F., Law A.J.L., Dalgleish D.G., Formation of soluble and micelle-bound aggregates in heated milk, J. Agric. Food Chem. 51 (2003) 4652-4660.

[19] Hardham J.F., Effect of protein standardization of milk by addition of UF milk permeate on the composition and storage stability of UHT processed milk, Aust. J. Dairy Technol. 53 (1998) 22-27.

[20] Holt C., Dalgleish D.G., Jenness R., Calculation of the ion equilibria in milk diffusate and comparison with experiment, Anal. Biochem. 113 (1981) 154-163.

[21] Horne D.S., Casein structure, self assembly and gelation, Curr. Opin. Colloid Interface Sci. 7 (2002) 456-461.

[22] Jean K., Renan M., Famelart M.-H., Guyomarc'h F., Structure and surface properties of the serum heat-induced protein aggregates isolated from heated skim milk, Int. Dairy J. 16 (2006) 303-315.

[23] Jou K.D., Harper W.J., Effect of disaccharides on the thermal properties of whey proteins determined by differential scanning calorimetry (DSC), Milchwissenschaft 51 (1996) 509-512.

[24] Kieseker F.G., Aitken B., An objective method for the determination of heat stability of milk powders, Aust. J. Dairy Technol. 43 (1988) 26-31.

[25] Klump H., DiRuggiero J., Kessel M., Park J.-B., Adams M.W.W., Robb F.T., Glutamate dehydrogenase from the hyperthermophile Pyrococcus furiosus: Thermal denaturation and activation, J. Biol. Chem. 267 (1992) 22681-22685.

[26] Newstead D.F., Sanderson W.B., Bauke A.G., The effects of heat treatment and $\mathrm{pH}$ on the heat stability of recombined evaporated milk, N.Z.J. Dairy Sci. Technol. 10 (1975) 113-118.

[27] Noh B., Richardson T., Creamer L.K., Radiolabelling study of the heat-induced interactions between alpha-lactalbumin, betalactoglobulin and kappa-casein in milk and in buffer solutions, J. Food Sci. 54 (1989) 889-893.

[28] O'Connell J.E., Fox P.F., The two-stage coagulation of milk proteins in the minimum of the heat coagulation time-pH profile of milk: Effect of casein micelle size, J. Dairy Sci. 83 (2000) 378-386.
[29] Oldfield D.J., Singh H., Taylor M.W., Pearce K.N., Heat-induced interactions of $\beta$-lactoglobulin and $\alpha$-lactalbumin with the casein micelle in $\mathrm{pH}$ adjusted skim milk, Int. Dairy J. 10 (2000) 509-518.

[30] Pouliot Y., Boulet M., Observations on the seasonal variation in the salt balance of concentrated milk, Int. Dairy J. 5 (1995) 75-85.

[31] Ralston G., Introduction to Analytical Ultracentrifugation, Beckman Instruments Inc. Fullerton California, USA (1993) pp. 8-10.

[32] Renan M., Mekmene O., Famelart M.-H., Guyomarc'h F., Arnoult-Delest V., Pâquet D., Brulé G., The pH-dependent behaviour of soluble protein aggregates formed during heat treatment of milk at $\mathrm{pH} 6.5$ or 7.2 , J. Dairy Res. 73 (2006) 79-86.

[33] Rodriguez del Angel C., Dalgleish D.G., Structures and some properties of soluble protein complexes formed by the heating of reconstituted skim milk powder, Food Res. Int. 39 (2006) 472-479.

[34] Singh H., Creamer L.K., Influence of concentration of milk solids on the dissociation of micellar $\kappa$-casein on heating reconstituted milk at $120{ }^{\circ} \mathrm{C}$, J. Dairy Res. 58 (1991) 99105.

[35] Singh H., Creamer L.K., Aggregation and dissociation of milk protein complexes in heated reconstituted concentrated skim milks, J. Food Sci. 56 (1991) 238-246.

[36] Singh H., Fox P.F., Heat stability of milk: $\mathrm{pH}$-dependent dissociation of micellar $\kappa$ casein on heating milk at ultra high temperatures, J. Dairy Res. 52 (1985) 529-538.

[37] Singh H., Latham J., Heat stability of milk: Aggregation and dissociation of protein at ultra high temperatures, Int. Dairy J. 3 (1993) 22-237.

[38] Vasbinder A.J., Alting A.C., deKruif K.G., Quantification of heat-induced casein-whey protein interactions in milk and its relation to gelation kinetics, Colloid Surf. B 31 (2003) 115-123.

[39] Vasbinder A.J., deKruif K.G., Casein whey interactions in heated milk: the influence of pH, Int. Dairy J. 13 (2003) 669-777.

[40] Williams R.P.W., The relationship between the composition of milk and the properties of bulk milk products, Aust. J. Dairy Technol. 57 (2002) 30-44

[41] Williams R.P.W., D’Ath L., Augustin M.A., Production of calcium-fortified milk powders using soluble calcium salts, Lait 85 (2005) 369-381. 